\title{
Impact and the Humanities: The Rise of Accountability in Public Cultural Life
}

\subsection{INTRODUCTION}

This chapter explores how certain kinds of assessment criteria influence the valuation of the humanities. In particular, I discuss the implementation of the impact score into the Research Excellence Framework (REF henceforth) in the 2014 cycle. In doing so, I demonstrate how the REF's valuation of impact primarily rewards research that produces a financial profit. This raises a concern for the humanities since research within cultural bodies of knowledge such as history, the arts, philosophy, and linguistics is not necessarily compatible with the market. The title of Stefan Collini's article in the Times Literary Supplement, 13 November 2009, encapsulates the threat: "Impact on Humanities: Researchers Must Take a Stand Now or Be Judged and Rewarded as Salesmen". The premise behind this critique is that an understanding of how value is measured has a profound effect on value itself. Therefore, this chapter interrogates the effects of assessment criteria upon the concept of public valuation of cultural knowledge in order to demonstrate the coercive effects of government policy, and consider the ways in which the humanities might resist such structures.

As Simon Smith et al. note, "as early as the 1993 white paper Realising Our Potential government science policy specified an impact imperative for UK scientific research" (2011, 1370). The initial demand of Realising Our Potential stated that "specific policies are designed to get maximum value for money from our annual public expenditure" (HMSO 1993, 5).

(C) The Author(s) 2020

Z. H. Bulaitis, Value and the Humanities, Palgrave Studies in Literature,

Culture and Economics, https://doi.org/10.1007/978-3-030-37892-9_5 
From a strategy for investment in "scientific research" (Smith et al. 2011, 1370), economic approaches have expanded into a universal system for research assessment across all disciplines. The 2014 REF impact criteria are exemplary of policy seeking to encourage measurable values in higher education. It is worthwhile to note that impact was present in higher education management rhetoric for several years preceding this formal framework. ${ }^{1}$ The 2014 REF submission guidelines, published by the Higher Education Finance Council for England (HEFCE henceforth), July 2011, define impact as follows: "[research] of direct relevance to the needs of commerce, industry, and to the public and voluntary sectors; scholarship; the invention and generation of ideas, images, performances, artefacts including design" $(2011,48) .{ }^{2}$ The priority of commercial and industrial activity is clear. Impact is knowledge that is immediately useful to society in the form of patentable-ideas, marketable images, cultural events, and products. The focus on external value and public accountability is further underlined by those areas expressly excluded from the REF's definition of impact: "the advancement of academic knowledge within the higher education sector" and "impacts on students, teaching or other activities within the submitting HEI" (HEFCE 2011, 48). ${ }^{3}$ This disregards a large percentage of the work that happens in the humanities, from teaching students to be critical thinkers, to building research communities to address socio-cultural concerns. The REF impact criterion values the form of tangible and public output, above the academic quality of such research. Collini argues that this presents a danger as "the only way to justify what goes on 'inside' universities is by demonstrating some benefit that happens 'outside" $(2009,19)$. Perhaps even "demonstrating some benefit" might not be necessary, as studies of abuses of the impact metric indicate. ${ }^{4}$ The act of creating something that can be valued is prioritised over the inherent properties of the research.

${ }^{1}$ See Donovan (2007); Spaapen et al. (2007).

${ }^{2}$ The REF's definition of scholarship does mean academic research, but is instead refers to "the creation, development and maintenance of the intellectual infrastructure of subjects and disciplines, in forms such as dictionaries, scholarly editions, catalogues and contributions to major research databases"; all of which are marketable products. See Annex C "Assessment framework and guidance on submissions" $48 \mathrm{fn}$.

${ }^{3}$ The acronym HEI stands for higher education institution.

${ }^{4}$ For an example of the recent abuse of impact metrics see Roelofs, P. and Gallien, M. (2017), who discuss how "the academic equivalent of a Trump tweet, clickbait with footnotes" received the highest readership in development studies journal Third World Quarterly. See also Ioannidis, J. (2005). 
Attentiveness to the language of assessment reveals the extent to which business and management models have been incorporated into the operation of higher education. In addition to critiquing what the impact criterion seeks to measure, Collini identifies the equally important task of challenging the language that is used to evaluate research. He wonders if perhaps "our ears no longer hear what a fatuous, weaselly phrase 'Research Excellence Framework' actually is, or how ludicrous it is to propose that the quality of scholarship can be partly judged in terms of the number of 'external research users' or the range of 'impact indicators'" $(2009,19)$. How and why research is evaluated needs to be placed under scrutiny. Scholars of the humanities scarcely need to be reminded of the significance of language and its use. Martin Heidegger's Letter on Humanism describes language as "a house of being" and argues that "those who think and those who create with words are the guardians of this home" $(1946,147)$. Heidegger's philosophical conception of language emphasises the relationship between the words we use and the way we think. For Heidegger, the language with which we think shapes the possibility of thought itself: "thinking comes to an end when it slips out of its element" (149). The accusation is that an instrumental framework is insufficient for describing the values of humanistic study and that each iteration denatures such endeavours. Heidegger writes how in "slipping out of its element it replaces this loss by procuring validity for itself as techne, as an instrument of education" (150), and how "the widely and rapidly spreading devastation of language not only undermines aesthetic and moral responsibility in every use of language; it arises from a threat to the essence of humanity" (151). The broad values of the humanities, of the experience of being human, are reduced to an economic instrument in the language of the research assessment.

The Research Council UK's (RCUK henceforth) mission statement: "Ensuring Excellence with Impact" is a likely candidate for language that Heidegger identifies as devastating, or that Collini describes as "economistic officialise" $(2009,19) .{ }^{5}$ The word "excellence" is a competitive value judgement. The superlative nature of excellence, alongside the guarantee that it can be ensured "with Impact" is representative of the dominant kind of rhetoric used to describe value in higher education.

\footnotetext{
${ }^{5}$ See RCUK (2011).
} 
The idea of "excellence" has been extensively critiqued. ${ }^{6}$ Moore et al.'s article, "Excellence R Us': University Research and the Fetishisation of Excellence", describes how:

\begin{abstract}
Although, as its ubiquity suggests, "excellence" is used across disciplines to assert value judgements about otherwise incomparable scientific and scholarly endeavours, the concept itself mostly fails to capture the disciplinary qualities it claims to define. Because it lacks content, "excellence" serves in the broadest sense solely as an (aspirational) claim of comparative success: that some thing, person, activity, or institution can be asserted in a hopefully convincing fashion to be "better" or "more important" than some other (often otherwise incomparable) thing, person, activity, or institution — and, crucially, that it is, as a result, more deserving of reward. $(2017,3)$
\end{abstract}

Moore et al. highlight the ambiguity of the language of excellence and a desire for the ability to measure success comparatively. The impact criterion promises a framework with which to transform the abstract ideal of excellence, described by Tim Hallett as a "macro-cultural myth" (2017, 54), into a statistical assurance. Returning to the RCUK mission statement "Ensuring Excellence with Impact", it is evident that by ensuring excellence with impact, the central role of accountability in the evaluation of research excellence is explicitly reinforced.

Therefore, I argue that answering the question of how the research criterion of impact changes valuation is twofold. First, the language of valuation is reduced to the definitive limits of the framework. In the case of the REF 2014 impact criterion, these are specifically market-oriented and output-driven projects. Second, the introduction of a limited set of metric values generates a competitive environment in which individual scholars must negotiate their worth in the terms of the framework in competition with one another, or cease to be valued. The adoption of the language of business into evaluations of higher education is the result of the extension of neoliberal governance into all public sectors in England. Instead of conceding that some parts of social life are incompatible with marketisation, policymakers have introduced a proliferation of governing strategies in order to address, and in many ways sought to obscure, this incompatibility. Impact is one such mechanism that aims to direct the work of universities towards attainment of value in the market, which

\footnotetext{
${ }^{6}$ See Readings, B. (1996) 21-43; Stilgoe, J. (2014); O'Connor P., \& O’Hagan, C. (2015) 1943-57.
} 
raises the question: what can the humanities do? Although Collini identifies that "economic officialise" $(2009,19)$ is a poor language with which to express the value of the humanities, and that the effects of assessment act to corrode long-held values in those disciplines, his article does not provide a clear indication of any alternative but rather that we must "take a stand now or be judged as salesmen" (19). The dissonance between an individual valuation of the humanities and the demands of a national policy framework is clear; this chapter addresses what can be done about this emergent context.

Thankfully, this reflective critique is already underway. ${ }^{7}$ As cited in the introduction, Helen Small reminds us that "it is part of the scholar's responsibility to keep reinterpreting and re-evaluating that cultural memory in the context of the now" $(2013,145)$. This chapter challenges the shift towards impact in the REF and establishes a sense of ownership that is presently lacking in this critical area of the valuation debate in the humanities. I achieve this by placing impact in dialogue with a longer history of accountability in cultural institutions in England. The implementation of market-metrics into the valuation of cultural life has been ubiquitous in policymaking practice since the 1980s. The argument of this chapter is that by exploring the effects of such measures in other sectors we can establish a language with which to critique these unsuitable and shortsighted metrics. The central examples of this chapter are public art galleries and museums: from their foundational policies in the nineteenth century to their neoliberal management techniques of the 1980s.

I argue that the current imposition of metrics in valuing higher education has strong parallels to debates around the accountability of museums. Therefore, analysis of debates in arts management and museology provides a rich field of critical thinking with which to view the emergent research assessment models within higher education in a clearer light. Such a response contributes to a discursive field of policymaking that is lacking in institutional memory within specific government departments, let alone across cultural policy as a whole. ${ }^{8}$ Without the benefit of a historical perspective of cultural valuation, debates about 'impact' in contemporary higher education can become reactive, anecdotal, and risk becoming

\footnotetext{
${ }^{7}$ See Harpham, G. G. (2011) 21-42; Rylance, R. (2016); Drakeman, D. (2016) 109-17.

${ }^{8}$ See Hillman, N. (2016) 331 describing the lack of continuity in staff and shared expertise within Whitehall.
} 
conflicts in which the terms of debate is set by policymakers forcing a reliance on empty aphorisms or regurgitated business-speak.

In order to develop a richer narrative, the first part of this chapter traces the roots of the justification of cultural institutions from their first iterations in the Victorian period. The founding of the British Museum demonstrates how public accountability was integral to the act of establishing the country's first national museum. This foundational moment in museum policy highlights how deep the roots of economisation are in the context of cultural valuation. Returning to the nineteenth century also offers critiques that are uninhibited by the limited vision of our particular neoliberal moment. The debates included in this section serve to demonstrate that whilst many of the tenets of accountability and narratives of public value were borne out of governance strategies in the mid-Victorian period, there were many other voices and ideas in the debate. This "commitment to pluralism" (Hadley 2005, 94) or "many-sidedness" (Thomas 2004,26 ) is an antidote to cultural policymaking in the 1980s, which follows. As highlighted in the introductory chapter, debates concerning Victorian liberalism capture the tension between the self-reflective individual and the pursuit of national economic interests in laissez-faire capitalism, and the disparities between aristocratic and middle-class proponents of the civilising potential of culture and those working class people excluded from educational privileges and access.

The second part of this chapter addresses the idea of accountability and audit cultures, retracing the adoption of New Public Management (NPM henceforth) strategies in the management of public museums during the 1980-90s. Of equal significance is the emergence of the creative industries under New Labour (1997-2010), in which the creative sector became further marketised. In addition to summarising these legislative changes, this section also investigates the extensive body of scholarship that accompanies the changing measurement mechanisms and assessment culture within public museums. This provides a valuable, although presently underused, resource for the academic humanities. The third and final parts of this chapter draw on critical and theoretical arguments established in the previous two sections and conclude that as humanities scholars come under increasing public scrutiny, it is vital to interrogate not only what we argue about, but how we argue, the terms of the debate, and the values they represent.

The need for such an inquiry has never been greater, given the escalation of accountability metrics and the demand for scholars to perform 
within such frameworks. HEFCE announced that impact would be "deepened and broadened" in the REF 2021, with policy set to implement the "previous intention to increase the impact weighting [from 20\%] back to $25 \%$ as originally proposed for REF 2014" (HEFCE 2017). Although HEFCE's phrasing is intentionally non-alarmist, with an emphasis being placed on going "back to" a "previous intention", this policy represents a significant increase. A sustained scholarly effort is required in order to respond to the poverty of language with which to talk about, and respond to, the challenges facing the value of research in the humanities. To this end, I turn to the richer discourse surrounding the changes in museum studies from the Victorian period to the present day.

\subsection{Part I: Debates in Public Access, Use, and Accountability in the Victorian Museum}

The relationship between Victorian museums and present-day institutions should not be downplayed. Tim Barringer observes that "among the great museums of the Anglo-Saxon world, a majority are creations of the Victorian era" (2006, 133). As Barringer notes, the physical buildings that provide the contemporary cultural public spaces are predominantly Victorian. ${ }^{9}$ It is important to recognise that the construction of museum spaces occurred simultaneously to the development of methods for organising public museums. Therefore, the Victorians not only built the walls of the galleries and museums that visitors experience today, but they also initiated the terms on which public museums would be debated and valued. In retracing these foundations, I explore how debates about public access and institutional accountability rose to prominence in policymaking concerning public museums in England.

The following discussion negotiates between individual use and government intentions on a societal scale. Debates concerning public museums range from the individual desires of philanthropists to offer an educative space for individual citizens to the ambition of grand displays of national and imperial powers on the world stage. In order to explore such tensions, I draw on the theoretical work of Michel Foucault. In this way,

\footnotetext{
${ }^{9}$ Examples in London include Tate Britain (1897), the Museum of Manufactures (1852 now the V\&A), the Natural History Museum (1881), but there are many collections across the country, such as the Royal Albert Memorial Museum in Exeter (1869), or Birmingham Museum and Art Gallery (1885). For further discussion see Barringer (2006, 139).
} 
this chapter follows in the footsteps of many Victorian studies, and indeed cultural studies, scholars who have explored the interrelation between knowledge, state power and the discipline of subjects. However, rather than retracing the well-worn pathways of Discipline and Punish (1975), which have already been excellently explored in works such as D. A. Miller's The Novel and the Police (1988) or Jonathan Crary's Techniques of the Observer (1990), this chapter makes use of the ideas of Foucault's later work, namely through an application of his concept of governmentality. This work opens up a space for a discussion of self-cultivation that is less readily compatible with the surveillance models in Foucault's earlier work. In "Victorian Studies and the Two Modernities" Amanda Anderson emphasises the significant difference between "the middle Foucault exemplifying the critique of society $[\ldots]$, and the late Foucault enacting the embrace of aesthetic modernity via his turn to ethos and the self" (2005, 198). In addition, Foucault's later work specifically engages with tracing the shift from liberalism to neoliberalism, addressing how the operations of contemporary mechanisms of governance regulate both the individual and the state. Before turning to the historical analysis of museum management, I first outline the application of Foucault's work on governmentality in the context of the Victorian museum.

\subsubsection{Defining Foucauldian Governmentality}

Foucault's work on governmentality is frequently cited in critiques of the operation of national museums in England. Scholars of cultural administration and museology often use the word 'governmentality' in passing and the term has become somewhat of a hollow reference, rarely interrogated, and seemingly representative of everything that is problematic about contemporary market-led governance. This section aims to replenish the current discourse in order for a precise critique of accountability culture in public value.

In February 1978 at the Collège de France in Paris, Foucault presented a lecture series entitled "Sécurité, Territoire et Population" [Security, Territory and Population] that introduced the concept of governmentality, which represented a radical turning point in his critical thinking. In 2001, Thomas Lemke identified that this work "remained largely unpublished" and the lecture series was first translated in its entirety into English 
in $2007 . .^{10}$ The lectures are of immediate use to this project since they concentrate on the historical genealogy of the state operating under neoliberalism. Lemke explains how "the semantic linking of governing (gouverner) and modes of thought (mentalité) indicates that it is not possible to study the technologies of power without an analysis of the political rationality underpinning them" (2001, 191). Governmentality thus describes the how of power and interrogates the ways in which apparatuses structurally enact political intentions. At the end of the lecture series, Foucault defined governmentality as follows:

1. The ensemble formed by the institutions, procedures, analyses and reflections, calculations, and tactics that allow the exercise of this very specific, albeit very complex power $[\ldots]$

2. The tendency, the line of force, that for a long time, and throughout the West, has constantly led towards the pre-eminence over all other types of power-sovereignty, discipline, and so on-of the type of power which may be termed 'government', and which has led to the development of a series of specific governmental apparatuses (appareils) on the one hand, and, to the development of a series of knowledge (savoirs).

3. The process, or rather the result of the process, by which the state of justice of the Middle Ages became the administrative state in fifteenth and sixteenth centuries and was gradually 'governmentalized'. (Foucault 1977-8, 108-9)

Foucault argues that governmentality is the dominant organising principle throughout the West. In capturing how the "calculations and tactics" of governance structures are integral to understanding the relationship between knowledge and power, Foucault shows that the process of running a government in this administrative fashion results in a self-reinforcing feedback loop. Foucault demonstrates that a government governs by many more means than upholding and writing the law. He argues that the action of how one governs is formative and it is through "the result of the process" $(1977-8,108)$ that power is established. In the example of general accountability indexes, a study of governmentality would observe how the action of accounting affects what is being counted. In the context of

\footnotetext{
${ }^{10}$ Foucault's lecture in which he defined governmentality was translated by Rosi Braidotti, and published in Ideology \& Consciousness (Autumn 1979).
} 
impact measurement, the designation of categories and the processes of calculating the value would have profound implications on the impact itself.

This conception is useful for this chapter for two reasons: first, it articulates how small-scale actions of governance culminate in system-wide effects. Using this theoretical understanding this chapter will explore how the language and mechanisms of evaluation influence social understanding of the cultural sector. Second, Foucault's idea of governmentality also provides a means through which an individual might intervene in ideology. He argues that "the tactics of government that allow the continual definition of what and should or should not fall within the state's competence, and so on" (109), understanding policy and governance as malleable and on-going instead of didactic and omnipotent offers a chance for critical intervention. With the relevance of this framework identified, the following section explores how scholars have used an understanding of state actions to engage in debates concerning the value of the public museum.

\subsubsection{National Interests in the Public Museum: Governance and Powers of Display}

Tony Bennett draws on Foucauldian theory in his scholarship on the public museum; he conceives of the Victorian museum as a site that transforms abstract ideas into calculable values. In The Birth of the Museum Bennett argues that the mid-Victorian period was "a significant turning point in the development of British museum policy in clearly enunciating the principles of the modern museum conceived as an instrument of public education" (71). He posits that the management of public museums was driven by "governmental strategies rather than from any commitment to democratic principles as unqualified ends in themselves" $(1995,246)$. In other words, Bennett argues that museums were never valued most highly by policymakers for their potential to produce a social good on an individual level. His conception of a museum as an apparatus relies heavily on a Foucauldian reading of how power operates within and through institutions. Bennett's reading offers significant insight into the national interests concerning the development of public museums during the nineteenth century. For example, he identifies the South Kensington Museum as the prototypical model of a space that is "both material and symbolic, of a power to 'show and tell' $[\ldots]$ to incorporate the people within the processes of the state" $(1995,87)$. In The Birth of the Museum, public institutions are conceptualised as sites for new strategies of governance in which 
citizens are encouraged to improve themselves. In opening up cultural knowledge to a public audience in this manner, self-regulation replaces active government intervention. ${ }^{11}$ The idea that the management of a public museum might have such coercive power is further evidenced in Tim Barringer's "Victorian Culture and the Museum: Before and After the White Cube" (2006), which demonstrates the commodification of knowledge in public museums during the nineteenth century. Barringer suggests that the South Kensington Museum was "large, impersonal, bureaucratic, systematic in its economic and political instincts" (137). Barringer reinforces Bennett's assertion that the priority of public museums operates above the level of the individual and is principally concerned with governance at a national scale.

Scholars have subsequently questioned Bennett's somewhat polemical argument that an "ambition towards a specular dominance over a totality" $(1995,66)$ is an inherent trait in the expansion of public museums. After all, such a vision leaves a visitor of the museum without agency. On balance, it should be noted that Bennett's The Birth of the Museum was published prior to the full translation of Foucault's late lectures, which provide a greater consideration for individual ethos. In his 2006 article, Barringer concedes that, despite the government's intention behind the South Kensington Museum, "the responses of museum visitors to displays and exhibitions often radically differs from the stated aims of the curators" $(2006,138)$. Bennett's work does not allow a space for the consideration that "the careful regulation of the visitor's body and behaviour [often] fails to result in the transmission of coherent ideological positions from curator to viewer" (Barringer 2006, 138-39). What a government wants a citizen to do, and what an individual actually does are two very different things. However, it is important to recognise that totalising control was the ambition if not the end result of public displays of culture. In Globalization and the Great Exhibition: The Victorian New World Order (2009) Paul Young identifies that "Bennett's analysis of exhibition space is open to the charge that it overplays the disciplinary impact of these events" (81). Young's work offers a more productive reading of the Foucauldian discursive capacity of public museums on a national scale, which avoids such grand claims concerning the control of individuals' actions. He

\footnotetext{
${ }^{11}$ Bennett further theorises the rise of governmentality in British politics elsewhere, writing in "Putting Policy into Cultural Studies" that under New Labour culture in its modern sense emerged "as both the object and the instrument of government" $(1992,26)$.
} 
recognises that although "the focus of Bennett's work falls upon the way in which exhibitions encouraged individual citizens to discipline themselves as productive members of the modern nation-state" $(2009,81)$ it is perhaps more useful to consider the state as a body in itself. In focusing on the user of the museum - the visitor to what Bennett describes as the "Exhibitionary Complex" (1995, 9)-The Birth of the Museum fails to acknowledge the ways in which the state itself is subject to discipline on an global scale.

The Great Exhibition of 1851 is testament to the global importance of exhibition culture, and the role of museums in representing national progress and power on an international stage. The Crystal Palace is exemplary of how cultural and industrial progress was manifested through display culture. Young identifies how the processes of exhibition "privileged the role of the Palace in disciplining nation-states as productive members of the modern global economy" $(2009,81)$. To quote Foucault's lecture, 1 February 1978, directly: "to govern a state will thus mean the application of economy, the establishment of a economy, at the level of the state as a whole, that is to say exercising supervision and control over its inhabitants, wealth, and the conduct of all and each, as that of a father's over his household and goods" (1977-8, 95). This paternalistic conception of the state is even in the domestic sphere, entirely economic. Young's association of the exhibitionary space as a representative economy in the Crystal Palace is arguably at work in the organisation of all Victorian public museums. Thomas Greenwood provides historical testimony for this in his chapter on "Why Should Every Town Have a Museum?" (1888), asserting that "we don't want Old England to be behind other countries" (390), citing America, France, Germany, and the Australian Colonies as competitive examples in this regard. Sharon Macdonald observes that, perhaps better than any other phenomena, museums allow "nation states to show their mastery over the world" (2006, 85). Robert Aguirre's Informal Empire further evidences the significance of imperial powers of display in the context of Mexico and Central America. Informal Empire demonstrates how during the Victorian era "entire cultures were miniaturized, domesticated, displayed, and made flat in descriptive lists and catalogues" $(2005,35)$. Aguirre draws on Bruno Latour's idea of inscription, which explores the consequence of flattening cultural knowledge into discrete "packages of information" (2005, xxiv), or "centres of calculation" (Latour 1987, 225). Accordingly, Aguirre argues that 
inscriptions solve the problem of scale; they reduce a world of ungainly objects into flat packages of information that can be reproduced, reshuffled, recombined, superimposed over one another, made part of a written text, and, most crucially, merged with "geometry" (i.e. three-dimensional relations) to represent the world out there. (2005, xxiv)

The national imperative to control and collect fits with the wider doctrine of imperialism. Such research supports claims that the Victorian museum should be understood as "a productive and reproductive social body" (Black 2000, 43). The museum makes manifest abstract notions-in this case the nation-by curating, organising, and exhibiting objects to represent it.

This section has detailed how national interests are essential in a consideration of the value of public museums to those in power in the Victorian period. The Victorian museum acts as a tangible manifestation of state knowledge on a national scale. Scholarly work has extensively explored the operation of transforming museum culture into a national asset. For example, in Museums and the Public Sphere Jennifer Barrett proposes that "emerging modern public museums were a vital part of the industrialization and colonial processes" owing to the ways in which "museums catalogued and presented socioeconomic and technological change to their audiences" $(2012,47)$. Amongst those involved in the development of public collections, Henry Cole was perhaps the most significant figure in the expansion and modernisation of museum culture in London in the mid-late Victorian period. ${ }^{12}$ Brandon Taylor describes how Cole saw the development of public museums as "a symbol and expression of how a great manufacturing nation should develop and instruct - and hence create - its subjects" $(1999,70)$. The development of self-regulating individuals is the end-point of governmentality. In this conception, with the market as a regulatory force, the subject that Cole created has an intensively restricted level of agency. However, this chapter does not consider the history of museums at a national level alone. The following section presents a narrative of the foundation of the British Museum in terms of the individual aspirations of its trustees and visitors. The study of the operation of the public museums through Foucauldian governmentality requires an understanding of the precise ways in which governance

\footnotetext{
${ }^{12}$ Henry Cole was a commissioner for the Great Exhibition of 1851 and the first director of the South Kensington Museum between 1857 and 1873. See Bonython \& Burton (2003).
} 
interacted with the public museum at an operational level. In Governmentality: Current Issues and Future Challenges (2011) Ulrich Bröckling et al. identify how, unlike broad critiques of ideology, studies of governmentality:

do not describe ideas or theories in terms of a true-false distinction and imply no opposition between power and knowledge. Rather, they investigate the discursive operations, speakers' positions, and institutional mechanisms through which truth claims are produced, and which power effects are tied to these truths. Studies of governmentality trace the contours of this productive power, which produces a specific (and always selective) knowledge and in this way generates definitions of problems and fields of governmental intervention in the first place. (12)

Bennett, Barringer, and Young have explored the implications of Foucauldian theory in generating the idea of a national social body and the concept of exhibition as a tool for representing and thereby extending state power. I examine the operations of government, the how of power, in order to better understand how the management of museums came to generate the idea of cultural public accountability. This builds upon the scholarly foundations discussed above, but marks a shift of focus from the effects and aspirations of power to the more mundane operation of power.

\subsubsection{The British Museum: The Rise of Debates in Public Accountability and Access}

To outline a history of the foundation of the British Museum is also to chart the birth of the idea of accountability in the cultural sector. The following narrative outlines the initial conception of the museum, and records how the government's conception of a 'public' museum led to a focus on access and accountability in its governance. The discussion progresses as follows: first, I provide a description of the motivations behind the museum; second, I introduce the two key challenges that the museum faced in its foundational years, namely access and accountability; third, I explore government actions in establishing Select Committees during the 1830s designed to ameliorate the above concerns. In doing so, this case study of the British Museum exposes the ways in which the culture of management and governance shaped the very idea of a public national museum. 
The British Museum opened to the public on 15 January $1759 .{ }^{13}$ The collection of Sir Hans Sloane (1660-1753), renowned physician, naturalist, and collector, formed the basis for the museums' display. His dying request formed the foundation for the first public museum in England. Sloane's will expressed that his collection should be used for "the improvement, knowledge and information of all persons" $(1753,3)$ and available for "the use and improvement of physic, and other arts and sciences, and [the] benefit of mankind" (3). When Sloane died, aged 93, the 71,000 objects in his collection were offered for sale to Parliament for $£ 20,000$. This was a low price for the collection and it is estimated that the value of the collection was closer to $£ 50,000$. Parliament agreed that Sloane's bequest was "of much greater intrinsick Value than the Sum of Twenty thousand Pounds" and resolved that the collection "be kept intire, and maintained fur the Use and Benefit of the Publick" (Journal of the House of Commons 1753a, 747). This opportunity was used by Parliament to combine the purchases of several bequests of books and manuscripts. ${ }^{14}$ The final Act was, therefore, not Sloane's alone but instead

an Act for purchasing of the Museum, or Collection, of Sir Hans Sloane, and of the Harleian Collection of Manuscripts; and for providing One central Re'pository for the better Reception and more convenient Use of the said Collections, and of the Cottonian Library, and of the Additions thereto. (Journal of the House of Commons 1753b, 838)

The Act became law on the 7 June 1753 when George II gave the royal ascent, founding the first national museum in England.

From the outset, the appointed Board of Trustees for the museum was closely related to Parliament. The British Museum Act of 1753 ordered that of "the forty-two member Board, nineteen were members by virtue of the position they held in government, and they were the important offices of the state" (Cash 2002, 21). The trustees were predominately high-ranking statesmen and aristocrats, including the Archbishop of Canterbury, the Speaker of the House of Commons and the Duke of Portland. This association between the management of the museum and

\footnotetext{
${ }^{13}$ The collection was initially located in Montagu House in Bloomsbury being obtained "as a repository for the infant establishment" according to the historian Henry Clarke in The British Museum: Antiquities and Natural History: a Handbook Guide for Visitors (1843).

${ }^{14}$ For detailed information about the contents and history of these other collections see Cash, D. (2002).
} 
Parliament remains intact to this day; the Prime Minister appoints fifteen members of the twenty-five-member board. In A Social History of Museums (1975) Kenneth Hudson explains that although the British Museum belonged to the state, those in charge of the museum's management were "exclusive, elitist and, not infrequently, precious" and notes that "visitors were admitted as a privilege, not as a right" (6). As the following section details, the museum's first trustees compromised Sloane's ambitions for an accessible collection.

In the six years between Sloane's death and the museum opening the trustees significantly reinterpreted the notion of public access. The manuscripts of Thomas Birch (1705-1766) provide an extensive record of the discussion amongst the initial trustees. ${ }^{15}$ By 1756, Sloane's designation of "all persons" (Sloane 1753, 3) was restricted by the Board of Trustees to "the Use of learned \& studious men" (British Library n.d., fol. 118-20). There was much discussion during the winter of 1756 of how to prevent "persons of mean and low Degree and Rude or ill Behaviour from Intruding on such who were designed to have free Access to the Repository" (British Library n.d., fol. 115). In Access to Museum Culture: the British Museum from 1753-1836 Derek Cash summarises that "the Committee was very explicit in categorizing people into classes and associating values to the classes and determined that one should not infringe upon the other" $(2002,37)$. The above comments concerning those of "mean and low Degree" clearly demonstrate the elitism that was manifest amongst the Board members.

In an attempt to control access to the collections, it was decided that entrance to the British Museum be based upon the personal recommendation of a member of the board. This restricted access to the extent that "no persons [...] whatsoever be admitted to Inspect or View the Collections but by a proper Authority from the Trustees" (British Library n.d., fol. 115). On opening in 1759 , visitors were required to acquire a ticket in order to access the collection (see Fig. 5.1).

These personal tickets were granted by Trustees and in order to attain one, an applicant needed to be an acquaintance of a Trustee, be able to write a letter of introduction (a cost prohibitive for some), or to have time to travel to London to leave their details with a museum porter for examination and potential entrance at a later date. In addition to the financial

\footnotetext{
15 "A Collection of Papers Relating to the Establishment and Government of the British Museum" are held in the British Library. See Add. MS 4449 fols. 115, 118-20.
} 


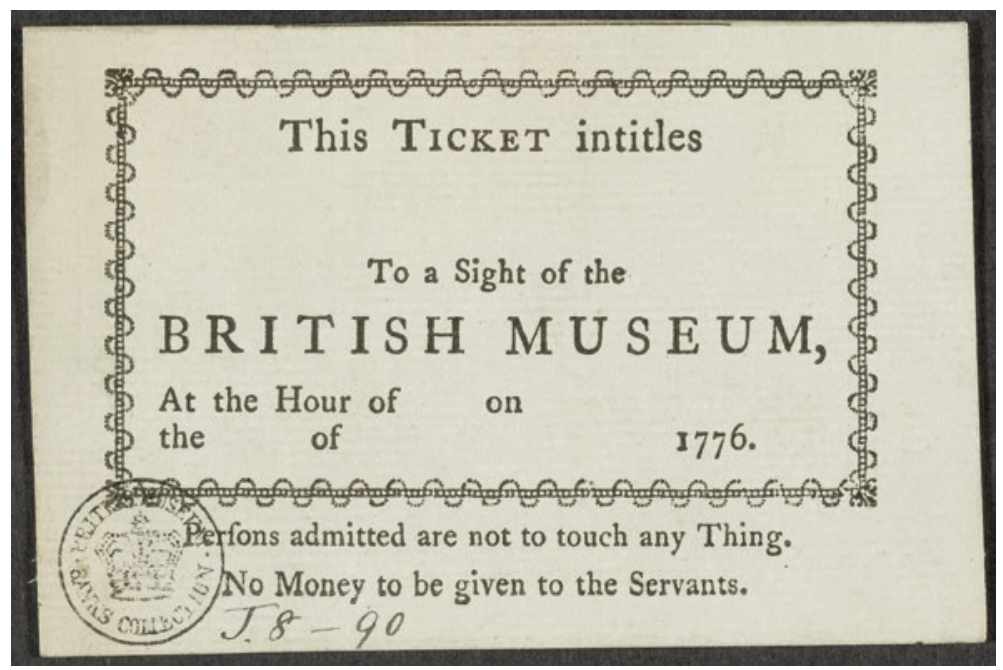

Fig. 5.1 A blank entrance ticket to the British Museum from 1776. Image source: The British Museum

barriers to entry, the process of applying for tickets excluded those who were unable to read and write. A large proportion of the public in $\mathbf{1 7 5 0}$ were illiterate and, although literacy greatly improved throughout the nineteenth century, as late as 1843 some $30 \%$ of men and approximately $50 \%$ of women were still unable to read, let alone write a personal letter requesting access to the British Museum. ${ }^{16}$

Beyond literacy, the financial cost of writing presents another significant limitation in public access to the museum. Robert Hume describes how "in the realm of cultural production, paper was vastly more expensive then than now" $(2015,379)$ and letter writing materials were a luxury to many households. Until 1840, the price of letters were charges to the recipient, meaning that if an individual wanted to gain access to the museum, they would need to have enough money to pay for the response letter from a trustee. Hudson describes how the process of applying for an

${ }^{16}$ Although literacy was considerably higher in London than in other areas, the ability to gain entrance was denied to many. For further data concerning literacy in specific regions see Cressy, D. (1980, 69-77). 
entrance ticket "was likely to take at least two weeks, and the investigations into credentials could last as long as several months" $(1975,9)$. Edward Miller equally emphasises the restrictedness of this approach in That Noble Cabinet: A History of the British Museum (1973), describing how the process of entrance to the museum was "deliberately made as difficult as possible" (63). Consequently, there was a low rate of attendance in the first years after opening the British Museum. ${ }^{17}$

The above accounts demonstrate that, despite Sloane's clear instruction, the obstructive actions of the Trustees significantly restricted the public's access to the museum. In The British Museum: A History (2002) Sir David Wilson (former Director of the British Museum 1977-92) affirms that in the early years of the museum "the doors were only opened a crack" (14). Reports show that between 1759 and 1799, "visitors were not at all numerous, the maximum for some years about sixty a day" (E. Miller 1973, 64). To encourage an increase in public access was seen as undesirable in the day-to-day management of the British Museum during the late 1700 and early 1800s. The statutes and rules formed by the Board of Trustees in December 1756 outlines this management decision:

for altho it [The British Museum] was chiefly designed for the use of learned and studious men, both natives and foreigners, in their researches into the several parts of knowledge; yet being founded at the expence [sic] of the public, it may be judged reasonably, that the advantages accruing that it should be rendered as general, as may be consistent with the several considerations above mentioned. (British Library 1757, fols. 18-25)

These founding rules acknowledged that the public funded the financial expenses of the museum. However, in the phrase "yet", it is possible to identify the roots for exclusion, since it discloses the secondary importance of public access to the primary use educated men within a closed circle. Therefore, the initial success of the Board of Trustees in establishing a public museum, open to all, is questionable at best.

\footnotetext{
${ }^{17}$ There are external factors such as the general level of public education, access to public transportation, and the social perception of London as being dangerous which may have contributed to low attendance in the first years. However, these external concerns are not the specific interest of this chapter, and the effects of management in the public sector, and therefore must remain an area to be taken up in future research. Source: "Accessing Enlightenment" British Museum Study Guide (2017, 2).
} 
Such negligence regarding the museums' founding principles attracted increasing attention in the press and Parliamentary debates of the 1820s and 1830s. A number of letters to the editors of The Times during the early 1820s expressed a frustration in struggling to access the British Museum and its reading room. One such letter, published on 10 October 1823 , authored by 'A Member of the University of Cambridge' reveals how "the reading rooms of this great national establishment are hermetically sealed against the majority of those who would wish to frequent them" (1823, 2). Another critical letter, published on 23 October 1823, corroborated that "abuses do exist in the quarters alluded to" ('Antiquarius' 1823, 3) and are "disgraceful to our national character" (3). A further letter, published 18 November 1825 using the pseudonym 'Syntax', provides an account of the "low shuffling tricks and petty prejudices" (4) of museum officials (citing Mr Planta and Mr Baber). ${ }^{18}$ The author complains of bureaucrats who "imagine that the best way of showing their authority is by excluding others, as much as they can, from participating of what is committed to their charge" ('Syntax' 1825,4). In these complaints it is the management of the museum, rather than the innate value of its contents, that are the subject of criticism. The idea that for the knowledge in a museum to be valuable it should be accessible and used by the public is implicit in these concerns.

Similar alarms over limitation of access were taken up in Parliament during the 1820-30s. On 16 February 1821, Thomas Barrett Lennard, Whig MP for Ipswich, argued that

considering the large sums which had been paid from the public purse for the establishment and maintenance of this institution, he must say, that those grants were very improvidently made, should it turn out, that instead of being found available for a public purpose, it was merely an establishment for the gratification of private favour or individual patronage. (Hansard " $\mathrm{Mr}$ Lennard", col. 724)

The ideas of the "public purse" and the "public purpose" of museums neatly capture the notion that accountability was to serve individual

\footnotetext{
${ }^{18} \mathrm{Mr}$ Joseph Planta was the Principal Librarian at the British Museum from 1799 until his death in 1827, and previously had held an assistant librarian position since 1773. Mr Henry Hervey Baber assumed a junior role at the museum in 1807 and was appointed to the office of keeper of the printed books in 1812 . He resigned the role in response to the recommendation of a Select Committee into the Museum Management in 1836.
} 
citizens but also to the national Treasury as a governing body. ${ }^{19}$ As with the example of the Great Exhibition in 1851, Parliamentary interest in the public museum is rooted in a concern for the perception of the nation. There are numerous comments from MPs in the House of Commons throughout the 1820s that negatively compared the level of access to the British Museum to public institutions in France, Italy, and elsewhere in Continental Europe..$^{20}$ In the same speech cited above Lennard proposed that, in addition to being disadvantageous to individual museum visitors denied access, it was "not honourable to the character of this country" for access to cultural knowledge to be restricted.

Substantial changes to the management of the museum in terms of accountability from Parliament began in the 1830s. This delay between the sentiment of the public and MPs and legislative action may be attributed to the relocation and the extensive building work at the British Museum that took place during the late 1820s and early 1830 s. $^{21}$ Growing Parliamentary concerns resulted in the establishment of the Select Committee into the Condition, Management and Affairs of the British Museum during the 1830s. The Select Committee Reports, published in 1835 and 1836, offer valuable insight into the emergence of the narrative of accountability. During this time, close scrutiny was given to the operation of the museum, from wages and salaries of museum officials to the recording of visitor numbers. The reforms and debates of the 1830s mark a shift towards accountability based on the collection of data to demonstrate efficacy in the management of public money. The reports of the 1835-36 Select Committee hearings amount to more than 1500 pages of evidence. The Report from the Select Committee on Condition, Management and Affairs of British Museum, 14 July 1836, reached several resolutions that primarily concerned the organisation of the board and the

\footnotetext{
${ }^{19}$ This relates to the discussion of Frow's image of the contradictory contacts of liberalism cited in Chap. 1, see Sect. 5.4.1.

${ }^{20}$ For example, see Mr Grey Bennett in the House of Commons Debate on 29 March 1824, vol. 10 col. 1467 and Lord Althorp in the House of Commons Debate on 25 March 1833, vol. 16. col. 1004 .

${ }^{21} \mathrm{~A}$ shift of conversation from access to building plans is noticeable in 1823-4. See HC Deb 1 July 1823 vol. 9 cols. 1357-6 and HC Deb 29 March 1824 vol. 10 cols.1466-76. However, by the mid-1830s with the renovation of the physical museum underway, the conversation returned to visitation and accountability to the wider public for whom the museum was intended.
} 
organisation and hiring of department heads within the museum. The report also implemented the extension of visitation hours for the public stating that "the Museum shall be open on Public Days be hereafter from Ten o'clock until Seven throughout the months of May, June, July and August; and that the Reading-Room be opened throughout the Year at Nine o'clock in the morning" (Parliamentary Papers 1836, iv). The museum was also to be "opened during the Easter, Whitsun and Christmas weeks, except Sundays and Christmas-Day" (1836, iv). These improvements to access were recorded in terms of number, closer scrutiny of salary, number of employees, and increased hours of visitation for the public. The effects were calculated in equally arithmetical terms: visitor numbers slowly increased "from 35,581 persons in $1815-16$ to 99,112 in 1830-31" (E. Miller 1973, 146); by 1875 there were 573,317 visitors and there were "655,688 five years later, and 767,402 in 1882" (257).

Following the publication of the Select Committee reports, the government was highly interested in the accountability of the public museum. For example, William Ewart argued that "it could not be denied by any rational man that this great institution should be thrown open, to the public who paid so liberally for its maintenance" (Hansard 1836a, col. 310 ). Such perceptions are at the root of accountability being presented in exclusively economic terms within the context of public cultural institutions in England. One of the museums' trustees, Reverend Josiah Forshall, lamented this change during the 1835 Select Committee hearing:

we have $[\ldots]$ an impediment in the very freedom of our political constitution: the necessity of perpetual reference to the House of Commons, the jealousy of that House in regard to the mode in which the public money is expended, the clamour, more or less prevalent, for economy, furnishing sometimes a reason with the Government for declining expense, and always a convenient excuse; these are obstacles in a great measure peculiar to this country, and they tend to prevent that course of dignified liberality in many points. (Parliamentary Papers 1835,45 )

Explaining expenditure and justifying the accountability to Parliament became part of the management of the British Museum. Forshall demonstrates how the demand for access and openness, a public purpose, became conflated with the cost of the museum, and the effect on the public purse. 


\subsubsection{The Rise of Accountability: Quantification as Justification in the Victorian Museum}

The emphasis placed on visitor numbers during the British Museum Select Committee hearings throughout the 1830s provide clear signs of the quantification of the value of public museums. Furthermore, discussions of opening hours and other numerical data became the focus of Parliamentary debates concerning the purpose of museums. This section details how this emergent metric evaluation, developed from its foundations in the management of the British Museum particularly in regard to defining institutional accountability.

William Jevons provides a vivid description of the measurement of visitor numbers at South Kensington Art Museum. His essay on the "Use and Abuse of Museums" (1881) outlines several criticisms concerning the deficiency of calculating the value of museums in numerical terms. Jevons argues that the calculation of footfall inside the museum is of no significance to understanding its value. He satirically describes how the museum administrators "make a great point of setting up turnstiles to record the precise number of visitors, and they can tell you to a unit the exact amount of civilising effect produced in any day, week, month or year" $(1881,54)$. 'They' are the collectors of evidence or, more precisely, the captors of the elusive notion of public value. ${ }^{22}$ Jevons' critique of turnstiles challenges the notion that a museums' success can be calculated by quantitative means. In defence of his claim that the mechanisms of measurement are insufficient, Jevons raises "the well-known fact that the attendance at Museums is greatest on wet days" (54). Inclement weather exposes how the valuation of footfall is an inadequate measurement of the use of the museum as a museum, as opposed to a shelter from the rain or a capacious and dry place for children to play.

Museums and the Public Sphere describes how "the museum as a space of leisure is not a new phenomenon" (Barrett 2012, 58). Barrett observes that since the mid-Victorian period "people used to picnic in the galleries of the Louvre and the British Museum" (58). This image undermines the idea of the museum as a solely educative space and introduces the free play of individual experience and usage. Whilst the majority of this chapter has concentrated on the perspectives of the policymaker and the museum

${ }^{22}$ The turnstile is a particularly significant representation of the reductive quantification of the arts and humanities. See, for example, Frank Parkin's The Mind and Body Shop in which "students entered the lecture theatres [...] through coin operated turnstiles" $(1987,13)$. 
trustee, it is worth considering that, since the mid-1800s, the public has regarded museums as more than simply a venue for the acquisition of knowledge. Jevons affirms that in the nineteenth-century museums were a form of entertainment: "many go to a public Museum just as they take a walk, without a thought or care as to what they are going to see" (1881, 54). ${ }^{23}$ It is significant to note that in the House of Common debates above, there was little attention paid to the motivations for museum visitation. For Jevons, the difficulty of calculating a fixed value of a museum through footfall is rendered useless since the building is additionally valued as a shelter, as well as a site of education. His suspicion of quantifying museum experience, despite his bias as a leading economist, is significant. It points to an interest in the agency of individuals, as self-cultivating, capable of improvement, and able to resist the state's structures of governance.

In "Why Should Every Town Have a Museum?" Greenwood argues that museums are beneficial "for young people of both sexes [as] they afford a place for recreation to which they can go, instead of loitering aimlessly about the public streets" $(1888,390)$. Although educational reforms, such as the 1870 Elementary Education Act, would improve school attendance and the quality of education this "was only the start of a process which would take more than twenty years to complete" (Gillard 2011). Therefore, during the 1850-70s the moral instruction of young people remained a particular concern among social reformers. Greenwood's declaration offers a marked shift from the reluctance of the British Museum's first Trustees to admit "persons of mean and low Degree" (British Library n.d. fol. 115) into the collections. By the second half of the nineteenth century, the abstract idea that museums were of general civic benefit had entered popular discourse. John Tenniel's cartoon "The Sunday Question. The Public House; or, The House For The Public?" published in Punch, 17 April 1869, visualised a citizens choice between imbibing, at the "Public House", or the civilising power of education at the museum, "the House for the Public" (see Fig. 5.2).

In On Exhibit: Victorians and Their Museums (2000) Barbara Black identifies that museums "competed directly with the public house by offering evening hours and specifically targeted exhibits" (33). This reinforces Greenwood's perspective that the presence of a public museum has a civilising function. Both Tenniel and Greenwood regard the museum as a better alternative to loitering or consuming alcohol, but fail to provide

${ }^{23}$ For a contemporary perspective on this, see van Aalst \& Boogaarts (2002). 


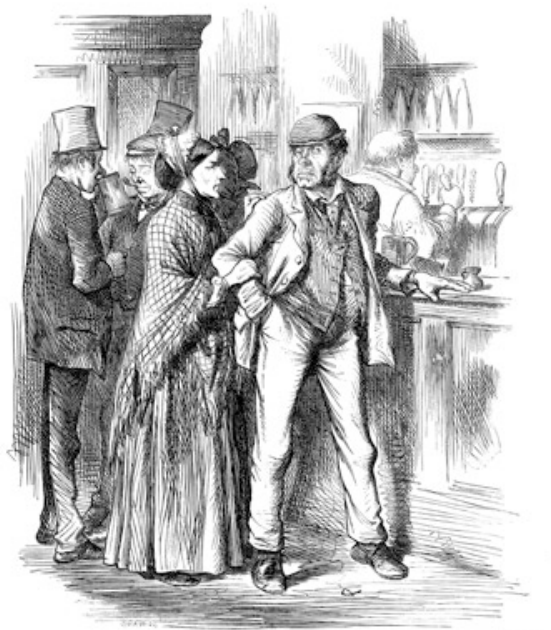

THE SUNDAY QUESTION.

THE PUBL.lс-HOUSE;

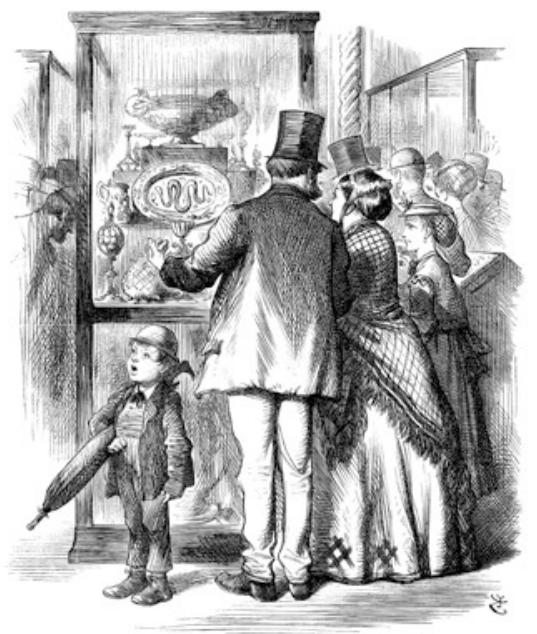

or:

THE HOtsE FOR THE PUBLIC?

Fig. 5.2 John Tenniel. "The Sunday Question. The Public House; or, The House For the Public?” Punch, 17 April 1869

any description of how museum attendance directly benefits the individual. For example, Greenwood states that "a Museum and Free Library are as necessary for the mental and moral health of the citizens" $(1888,389)$ and are as important as "good sanitary arrangements, water supply and street lighting are for their physical health and comfort" (389). Greenwood presents museum access as essential as the basic need for water. Greenwood and Tenniel assume that museums have value simply by existing, as if an exposure to hallowed objects inevitably makes visitors more civilised, both through the development of personal moral qualities but also in terms of nationalistic consciousness. Within Parliament, Joseph Hume encapsulates this abstracted belief in the civilising potential of the museum, speaking on 30 May 1836, he argues:

[The] British Museum was an exhibition maintained at public cost, and which, therefore, ought to be open to the public upon all possible occasions. For the mechanic to spend his Sunday afternoon with his family in the Museum appeared to him (Hume) a much better disposal of his time than if he were to resort to the public house or the gin palace. [...] The soldier and 
the mechanic of Paris derived a much higher elevation of mind, and a consequent higher tone of morality, from spending their Sunday afternoon in the Louvre than from besotting themselves in a cabaret. (Hansard "Mr Hume", col. 1160)

Hume's assumption that attendance at the museum might act as a panacea for social ills reveals a national interest in creating an obedient working and middle class. The comparison between England and Paris is indicative of an interest in national representation, rather than the cultivation of individual benefits as ends in themselves.

There has been little improvement in the national interest of calculating the value of an individual's experience within a museum since the nineteenth century. Attributing value to museums beyond the number of visitors is a challenging task; therefore it is unsurprising that the convenience of numeric calculation has come to dominate discussions regarding the public value of museums. However, the above history reveals that this decision is not only convenient or demonstrative of a preference for statistical datum over qualitative statement but also revelatory of the ideological conception of the museum, above all else, as a national socio-economic commodity.

\subsubsection{Conclusions, Regarding the Victorian Public Museum}

Thus far, I have considered the key tenets of the establishment of the idea of the public museum and shown how exhibitionary power operates through, and as a result of, mechanisms of governance. The roots of accountability, both in terms of government funding structures and the political rhetoric surrounding the civilising potential of access to public museums, have been articulated through the examples of the British Museum and the South Kensington Museum. Criticisms of capturing value using quantitative measurement have also been identified. These foundational arguments will be developed in discussing contemporary museums, in which institutions are increasingly required to make themselves accountable to the Treasury through increasingly bureaucratic procedures. I argue that, as Foucauldian governmentality suggests, the processes of policymaking have a profound effect on the results. Although the rise of accountability within museums came to be prominent during the Parliamentary debates on the British Museum during the 1820s and 1830s, the systemic requirement for museums to create case studies of 
impact and calculate their worth in economic terms is a uniquely latetwentieth-century phenomenon.

Therefore, the second part of this chapter demonstrates the further applicability of Foucauldian governmentality to museums in contemporary England. I argue that during the 1980s the "calculations, and tactics that allow the exercise of this very specific, albeit very complex, power that has the population as its target, [and] political economy as its major form of knowledge" (Foucault 1977-8, 108) became deeply ingrained. This is principally because of the advent of neoliberalism as the dominant political rationality of government, in place of the liberalism of the late-nineteenth century. Lemke's "The Birth of Bio-Politics" (2001) argues that the key difference between the two frameworks is that neoliberalism rejects "the rational principle for regulating and limiting the action of government in a natural freedom that we should all respect" and instead favours "an artificially arranged liberty: in the entrepreneurial and competitive behaviour of economic-rational individuals" (200). The adoption of economic value as the driving rationality of governance within the cultural sector exemplifies the full implications of Foucauldian governmentality. Beyond its application within the context of the Victorian public museum, a large body of scholarship draws upon governmentality in order to examine the rise of accountability in cultural policymaking. ${ }^{24}$ In particular, Nikolas Rose's "Governing by Numbers" (1991) observes how Foucault's late lectures describe the emergence of statistics as "one of the key modalities for the production of the knowledge necessary to govern, rendering the territory to be governed into thought as a domain with its own inherent density and vitality" (676). The density and vitality of this econocratic decisionmaking process under neoliberalism is interrogated in the following discussion of Thatcherite New Public Management models and the conception of the idea of the creative industries under New Labour.

\subsection{Part II: Public Expenditure and Public Values}

During Margaret Thatcher's Conservative administration (1979-90) the means of evaluating cultural organisations were drastically altered. ${ }^{25}$ Although Thatcher's government is remembered for substantial budget cuts across the cultural sector, the economisation of the value of the

\footnotetext{
${ }^{24}$ See Rose, N. (1991); Schlesinger, P. (2013); Donovan and O'Brien (2016).

${ }^{25}$ See Halsey, A. H. (1997); Belfiore and Bennett (2008).
} 
cultural institutions has instigated longer lasting effects. ${ }^{26}$ During the 1980s the rhetoric of economic justification became a formal requirement for government subsidy of creative and cultural ventures. This section explores how this system of governance came to prominence, describing the rise of New Public Management and the transformation of creative knowledge into a market commodity. The following analysis provides a wider context within which to locate the present changes occurring within higher education. A discussion of the creative industries reveals how, as far as policymakers are concerned, there is little space for value outside of the market. However, drawing upon the foundations of governmentality established in this chapter's previous section, allows for critical interpretations of the myopic system of evaluation. Following Bröckling et al. I demonstrate how studies of governmentality are "aimed above all at such programs and procedures. By contrast, the forms of resistance and counterconducts $[\ldots]$ are contingent. They have to be accounted for, but they are not calculable. There is a science of government, but there cannot be one of the art of not being governed" $(2011,17)$. The following section outlines the "programs and procedures" that construct the valuation culture that has come to dominate public cultural life, and now threatens to monopolise research assessment in higher education. I return to the idea of developing contingent "forms of resistance" once the objects and objectives of governance are clearly defined.

\subsection{1 "There Is No Alternative": The Rise of Economic Models of Valuation in the Cultural Sector}

In "The Birth of Bio-Politics" Lemke identifies that "the theoretical strength of the concept of governmentality consists of the fact that it construes neo-liberalism not just as ideological rhetoric or as a political economic reality" but rather a "political project that endeavours to create a social reality that it suggests already exists" $(2001,203)$. The dominance of economic value is so powerful because it obscures that it is a 'position', and asserts that it is a 'truth', creating what Mark Fisher describes as capitalist realism: "a pervasive atmosphere, conditioning not only the production of culture but also the regulation of work and education" (2009,

\footnotetext{
${ }^{26}$ See obituaries for Thatcher such as Billington, M. "Margaret Thatcher Casts A Long Shadow" (8 April 2013). Note also that the 2010s saw cuts to public funding in the arts in the UK which are worse than under Thatcher. See Cartwright, A. (2011).
} 
16). Thatcher's neoliberal slogan "there is no alternative" further encapsulates such an attempt at the creation of a totalising socio-political space. Whilst Thatcher believed that "economics are the method; [and] the object is to change the heart and soul" (1981), this section argues that the method itself is the most effective means by which cultural values are controlled. Once economic valuation was accepted into the logic of cultural policymaking it became increasingly difficult to imagine an alternative. David Looseley contends that "it is essential for the humanities to constantly point out that the market too is a narrative rather than an incontrovertible datum" $(2011,14)$. Economic valuation is by no means natural; it is imbued with biases that have serious consequences both inside and outside of the academy. The principal difficulty in undermining the persuasive power of economic thinking is the appearance of objectivity, or neutrality, of data. Bodies of data are seen as matters of fact as opposed to particular positions. However, by drawing upon theories of governmentality and focusing on strategies and tactics of governance, this section seeks to "reveal what is presented as necessary and inevitable to be a mere contingency" (Fisher 2009, 17). In drawing attention to the construction of value, of the mechanisms of a particular political project, it becomes possible to articulate that there is an alternative.

\subsubsection{New Public Management}

In The Politics of Culture (2012) Munira Mirza describes the 1980s as the decade in which

new criteria and assessment came into being $[\ldots]$ alongside more formalisation and bureaucratisation; increased centralisation through the creation of government departments and quasi non-government organisations (quangos); and the growth of statutory and non-statutory guidelines and policy frameworks. (44)

The rise of the New Public Management model offers one specific example of such "formalisation and bureaucratisation" (Mirza, 44). In short, New Public Management (NPM hereafter) is the "shift to a more managerialist approach to the public sector" with a specific "emphasis on efficiency, transparency, accountability, quality assurance, and competition" (Martin 
and Whitley 2010, 54). ${ }^{27} \mathrm{NPM}$ approaches can be applied to private companies, public institutions, and even to the development of countries as a whole. ${ }^{28}$ Barry Bozeman attributes the initial popularity of NPM to the context of economic austerity. He observes that NPM thrives as "nations strive to apply scarce resources to meet the needs and rising expectations of citizens" $(2007,7)$. The rhetoric of "doing more with less" complements the perception of scarcity. ${ }^{29}$ In "A Public Management for All Seasons?" Christopher Hood confirms that the benefits of NPM are "mainly in the direction of cutting costs and doing more for less as a result of better quality management and different structural design" (1991, 15). Hood accounts for the intellectual prominence of NPM as the system "offer[s] a neutral and all-purpose instrument for realizing whatever goals elected representatives might set" (1991, 10). NPM promises that better management tactics can transform "wasteful, fat, self-seeking, insensitive bureaucracies into fitter, leaner, more efficient and effective organisations which are closer to their customers and more accountable" (Clark 1991, $3)$. Under NPM, the market is perceived to be a means by which to avoid human complication within organisational systems. Claire Donovan and Dave O'Brien (2016) note that policymakers believed that "in the New Public Management the dominant form of organisation was the market as the type of social organisation that would not be subject to the problems associated with traditional public management" $(2016,27)$. The widespread adoption of this system marks the start of governance being driven solely by market rationale in England.

Although the roots of this approach are found in Thatcher's Conservative administration, the most conspicuous adoption of NPM in a policy document is New Labour's Modernising Government (1999). Tony Blair's (then Prime Minister) foreword to the white paper explains that "we are modernising our democratic framework" (Blair, 4) through an engagement "with how government itself works" (4). Modernising Government signifies the belief in the neutrality of market-based evidence at the most fundamental level of government. The report praises the adoption of

${ }^{27}$ See Barzelay, M. (2002) for further definition.

${ }^{28} \mathrm{NPM}$ is not a solely UK phenomenon and it is influential in Canada, Australia, New Zealand, and a large number of OECD (Organisation for Economic Co-operation and Development) countries. See McLaughlin et al. (2002).

${ }^{29}$ This can be observed in political campaigns such as, then Prime Minister, David Cameron's "The Big Society", which was driven by the idea of using "people power" in communities to initiate change, without the increase in funding or governmental support. 
NPM under Thatcher, which had "brought improved productivity, better value for money and in many cases better quality services" (HMSO 1999, 22). Modernising Government guarantees that in the future "all public bodies are properly and fully accountable to the public" (32). In The Social Impact of the Arts: An Intellectual History (2008), Eleonora Belfiore and Oliver Bennett describe how this adoption of "evidence-based policy was intended to signal the end of ideologically driven politics" (5). Evidencing value in this way reflected NPM's aspiration for neutrality. Belfiore and Bennett chart the emergence of this policy preference in the medical professions during the 1990s and its spread across other sectors of governance. The integration of accountability in museums is only one example of the dominance of NPM across the public sector. Peter Miller describes how, with the adoption of NPM, "the calculative practices and language of accountancy have seeped into everyday life" $(2001,391)$. Beyond the management of exclusively economic affairs, the methodologies of NPM came to be seen as offering policymakers, funders and administrators "a neutral and all-purpose instrument" (Hood 1991, 10). Michael Sandel reminds us that such measurement only "seems to be non-judgemental" (2009, my italics). In reality, there are many values implicit in prioritising evidence-based policy, especially within the context of cultural value, which have significant consequences on culture itself. The power of NPM is that it allows for a forgetting, or an obscuring, of the ways in which its models work by offering a language that depoliticises the market with the claim that "there is no alternative".

\subsubsection{Responses from the Cultural Sector}

The above analysis of NPM reveals that a faith in "incontrovertible datum" (Looseley 2011,14 ) is, in fact, part of an ideological process. Fisher notes how "what is currently called 'realistic' was itself once 'impossible" (2009, 17) and argues that recognising contingencies of value is vital in constructing a critique. To date, scholars of museum studies have interrogated the politics of data collection arguing that the mechanisms that account for the value of culture are inadequate. They contend that assessment criteria emphasise the importance of outputs, which results in an individual's experiences of culture being subsumed into the demands of national socio-economic strategies. As seen above, this criticism dates back to the foundations of public cultural institutions in England. Critics have also documented the erosion of intrinsic value in the context of marketisation. 
In Capturing Cultural Value (2004) John Holden expresses the deficiency of the rhetoric of economic efficacy: "we need a language capable of reflecting, recognising and capturing the full range of values expressed through culture" (9). Both the development of increasingly specific and output-led assessment criteria and the rise of economic languages to describe value, such as the 'creative industries', are the result of governing using NPM approaches.

The most commonly levelled criticism of processes of valuation within museums is that the mechanisms that determine value are insufficient. Holden maintains that such "concentration on instrumental 'impacts and outcomes' has produced organizational and systemic distortions" (2004, 19) within the cultural sector today. These distortions are created in response to the "impact" assessment criteria for funding and the positive bias towards cultural proposals that demonstrate wider socio-economic benefits. Hasan Bakhshi et al. pragmatically remind us that "whether we like it or not, governments choose between alternative expenditures. They cannot spend the same pound twice on a hospital and an art gallery" $(2009,17)$. Such a fiscally motivated argument relies on the belief that the mechanisms that set out to establish an accountable, socially valuable, economically viable museum work. ${ }^{30}$ However, focusing on outputs often undermines the inherent value of the creative work and leads to a poorer quality result. Cultural institutions dedicate a large amount of time to justify their impact and value rather than concentrating on creating work that produces it. Holden describes the effect of this audit culture, envisioning how

all around the country, cultural organizations - museums, theatres, arts centres and the rest - are holding away days to update their business plans. Library managers are drawing up budgets for their local authority bosses, and voluntary groups are filling in forms, seeking resources to restore historic buildings. They all need money, and they are competing for the attention of those who take decisions within that amorphous beast, the 'funding system'. $(2004,13)$

Holden argues that a significant portion of institutional attention is diverted towards developing business plans and writing funding proposals

\footnotetext{
${ }^{30}$ For a critique of this assumption, see Selwood, S. (2002); Holden, J. (2004); O'Brien, D. (2010).
} 
as opposed to cultural work. The financial imperative within accountability agendas has led to institutional energy being "directed into chasing funding and collecting evidence rather than achieving cultural purposes" $(2004,20)$. The necessity to generate such data indicates the deep-rooted effects of economic accountability upon the sector.

These changes first impacted art galleries and museums during the 1980s. Anthony Field, the long-serving Finance Director of the Arts Council between 1957 and 1985 reflects on how, under the pressures of Thatcher's administration, he argued that

we must change the argument to get more funds. We must say that money spent on the Arts was not subsidy but investment. I produced statistics showing that for each one million pounds invested, the Treasury received three million from foreign tours and tourism, royalties and employment taxes. I led the Arts Council into its sad decline of quantifying the arts in material terms. (qtd. in Sinclair 1995, 129)

Although Field's reflections on the processes of quantification are personal, they speak to the wider national trends. Today, contemporary statements of value continue to be supported by statistics concerning their economic value. For instance, on their designated campaign page "Why Culture Matters" Arts Council England reported that "Art and Culture contributed $£ 7.7$ billion to the economy between 2011 and 2013 ". ${ }^{31}$ The website contains numerous statistics and an "advocacy toolkit" for making an effective case for the arts to funding bodies; "Why Culture Matters" is phrased in the efficient language of policymakers and relies solely upon instrumental values. The advocacy toolkit is divided into four categories in which culture adds value to society: education, health and wellbeing, society, and the economy. Focusing on outcome-driven valuation means that "instead of talking about what they do, they demonstrate how they have contributed to wider policy agendas such as social inclusion, crime prevention and learning" (Holden 2004, 13). Quantified metrics of instrumental benefits replace any qualitative or intrinsic benefits in a culture. Such an outlook even pervades international cultural projects; for example, UNESCO's “Creative Cities" project (2014-5) set out with ambitions to

${ }^{31}$ Economic evaluations encroach on the most existential of contexts: "reduced demand for GP and mental health services could already be saving the NHS $£ 500$ million a year" (Arts Council England). 
"draw together vibrant creative communities using culture to make cities thrive" $(2015,27)$. However, the report at the conclusion of the project celebrated the key result as having "generated an estimated $£ 2.4$ million from April 2014 to March 2015" (2015, 27). No other implications beyond the economic value of the project were included in the final report. For "vibrant creative communities" to "thrive" equates to the generation of financial revenue.

Sara Selwood's “The Politics of Data Collection" (2002) explores the bias inherent in using financial data as justification within the cultural sector. She posits that "much of the data produced about the workings of the cultural sector have been criticized as methodologically flawed and [...] say more about policy intentions than about actual impact" (13). Selwood draws attention to a problem with data collection that has been around since Jevon's critique of the integration of turnstiles in the South Kensington Museum in 1888. Measuring 'actual impact' is not simply a matter of counting the number of people, or the revenue generated. There are increasing numbers of scholars interested in developing a language of 'cultural economics' as the preferred answer of how to account for these concerns, but others accuse such attempts of being "a sophisticated form of lying" (Hewison 2011). ${ }^{32}$ Regardless, this particular debate is beside the point, since it is obvious (to the point of tautology) that even the most advanced metrics for measuring the value of culture still inevitably engage with the dubious activity of condensing human experience into data. My stance is not that such valuation should be disincentivised, rather, that we also need scholarship and research that attests to the values that will always be overlooked however sophisticated the metrics. What is of higher significance to the present debate is the disparity between what museum curators, administrators, and staff perceive to be valuable in a cultural institution, and what is asked of them through funding and grant criteria. In a 2010 report for the Department of Culture, Media and Sport (DCMS henceforth), Dave O'Brien describes the "perceived distance between economics, which is the dominant language of government, and the cultural sector, which operates on a very different set of assumptions" (2010, 4). These particular assumptions are creative and humanistic and are most commonly expressed in intrinsic defences of the arts, which I outline below.

\footnotetext{
${ }^{32}$ For advocates of cultural economics see Bakhshi, H., et al. (2009).
} 
An intrinsic defence of the value of culture advocates that the public benefit of art is the aesthetic experience of art in and of itself, above and beyond any additional or consequential benefits social, economic, or otherwise. Kant's definition provides the orthodox reference for this view of value. In the Critique of Judgement (1790), he writes:

for although such art is capable of being at times directed to ends intrinsically legitimate and praiseworthy, still it becomes reprehensible on account of the subjective injury done in this way to maxims and dispositions, even where objectively the action may be lawful. For it is not enough to do what is right, but we should practise it solely on the ground of its being right. (\$53 327)

For Kant, and those who follow such a model of artistic valuation, the usefulness of aesthetic experience is self-evident. He argues that we ought to act on what is morally correct, indicating that acting in the interest of ancillary intrinsic aspirations, however "legitimate and laudable", "corrupts" the creative act. Kant further expresses such a sentiment in an earlier section of his critique, "Fine Art", arguing that "the universal communicability of a pleasure involves in its very concept that the pleasure is not one of enjoyment arising out of mere sensation, but must be one of reflection" ( $\$ 44306)$. Here, Kant maintains that the value of art comes from responding to its inherent properties. ${ }^{33}$ However, given the rise of accountability and output-led mechanisms for value it is increasingly hard to make such an aesthetic argument about an individuals' creative labour.

Established arts administrator, John Tusa is unashamed in his defence of the arts in intrinsic terms: "Mozart is Mozart because of his music and not because he created a tourist industry in Salzburg or gave his name to decadent chocolate" $(2000,103)$. Here, Tusa recognises that the value of Mozart's music has become conflated with the commercial benefits the 'Mozart brand' yields, and in doing so, we "have lost a vocabulary and an area of permitted public discourse where values are valued rather than costed" (29). Today, arguments that hark back to a cultural golden age of

\footnotetext{
${ }^{33}$ It is important to note, however, the difficulty of aligning Kant's philosophy as representative for all intrinsic value, as Bradley, B. (2006) attests "Kant utilized at least two different sorts of intrinsic value: one that is possessed only by good wills, and another that is possessed by all rational beings whether morally virtuous or vicious". Therefore, Bradley argues that Kant's attribution of intrinsic value is applicable to individuals but not to objects or phenomena.
} 
museums as sacred sites of cultural appreciation are somewhat misguided. ${ }^{34}$ The above discussion has shown that the motivations of our Victorian predecessor's for founding public cultural museums, and the subsequent judgement of the visitor experience are questionable at best. The testimonies of Greenwood, Jevons, and Tenniel chart the unpredictable "use and abuse" of public museums since their inception.

That said, Tusa's complaint is a specific and historically contingent response to the changes to mechanisms of cultural valuation in the late 1980s and 1990s. His observation that "public good is dismissed as a chimera so long as it cannot be quantified on a balance sheet" $(2000,30)$ is significant. Tusa's identification of the increasing demands on museums to evidence themselves on an exclusively economic scale of assessment criteria is beyond generic rejoinder. The sheer difficulty of making an intrinsic argument for the arts in the public sphere represents the dominance of economic value over all others. What is counted, and how it is counted, is presently no accurate account for value. Tusa argues that culture is, in and of itself, under threat: no longer valued but "costed" (29). The interrelation between mechanisms and metrics of value has established this homogeneity. Museums are thus required to provide calculable evidence in order to be valued despite the misrepresentative nature of the conclusions.

A report by Sara Selwood commissioned by the National Museum Directors' Council (NMDC) frames the tensions of thinking "intrinsic versus instrumental" most explicitly: "it is no good trying to relate all the value of arts and culture to monetary valuations" and yet it is "equally unhelpful to try to justify the arts as some kind of special case, different from all other spending priorities and subject to unique criteria" (2010, $5)$. Cultural institutions are caught in a difficult position, where they are forced to participate in the economic game playing, inherent in the funding models and policy demands, even if they understand these metrics to misrepresent their work. Bakhshi et al. highlight the "contradiction between the plea that the intrinsic value of art should be accounted for, and the idea that it is beyond accounting" $(2009,15)$. The increase of accountability metrics created an increased demand upon public cultural

\footnotetext{
${ }^{34}$ Instrumentality is not a new issue. Belfiore and Bennett (2008) argue that instrumentalism is " 2500 years old, rather than a degeneration brought about by contemporary funding regimes" (194) citing Plato's Republic as the first source of art being promoted as a means to achieve non-artistic ends.
} 
organisations to provide economic evidence in order to receive further funding. Under such conditions the possibility for articulating alternative values has become increasingly difficult.

With these considerations in mind, the final part of this section on contemporary museum policy moves beyond such stale divisions caricatured as the "floppy bow ties vs. hard-headed realists" (O'Brien 2010, 25). ${ }^{35}$ Whilst the division between intrinsic and instrumental value continues to form deep intellectual fissures between policymakers and practitioners, the division is more complex than this binary perspective allows. In fact, much to the dismay of those seeking to uphold traditional notions of intrinsic value since the late 1990s, there has been a conflation of artistic value with economic value. Theodor Adorno identifies this entanglement in the word "culture" itself. In "Culture and Administration" (1960) he writes "the inclusion of the objective spirit of an age in the single word "culture" betrays from the onset the administrative view, the task of which, looking down from on high, is to assemble, distribute, evaluate and organize" (107). If 'culture' is understood as the means by which to administrate the intrinsic "spirit of an age", then the notion of the 'creative industries' demarcates a particularly troubling state of affairs. The economisation of the arts and humanities is encapsulated in the prominence of the very term creative industries. The emergence of the notion of an "industry" of creativity in the last thirty years testifies to the difficulty of sustaining alternative modes of valuation beyond the market.

\subsubsection{The Arts and the Economy Embroiled: The Rise of the Creative Industries}

John Hartley describes the creative industries as a term that "combines but then radically transforms - two older terms: the creative arts and the cultural industries" (2005, 6 italics original). This definition demonstrates the ways in which the creative industries bring "the arts (i.e. culture) into direct contact with large-scale industries such as media entertainment (i.e. the market)" (6). In the era of creative industries, arts and humanities practices are "embroiled in markets in a more diffuse and plural sense, because their intellectual values are inevitably shaped by their social context and application" (Gibbons et al. 1994, 99). The developing

\footnotetext{
${ }^{35}$ Note this parallels the clichés concerning academics and chancellors within higher education outlined in the fictional representations in Chap. 4.
} 
relationship between industry and cultural knowledge production is a nuanced phenomenon that is not entirely positive or negative in regard to cultural value. That said, given the dominance of economically-minded valuation mechanisms, it is important that producers of creative knowledge are aware of the historical precedent, emergent tensions, and inherent compromises that the term "creative industries" suppresses.

The concept of the creative industries rose to prominence under New Labour. The Department for Culture, Media and Sport (DCMS) was established in 1997 under Blair, and the strategy of the creative industries continued to be encouraged under Gordon Brown through the 2000s. The 'creative industries' were first referenced in England in a series of "Creative Industries Mapping Documents" published by the DCMS in 1998. These documents catalogued sectors of creative and cultural production that were of perceived benefit to the British economy. The mapping documents define the creative industries as having "their origin in individual creativity, skill and talent and which have a potential for wealth and job creation through the generation and exploitation of intellectual property" (DCMS 1998). The creative industries have, therefore, always valued culture in terms of economic potential. ${ }^{36}$ The annual Creative Industries: Focus On report for 2016 details how "exports of services from the Creative Industries accounted for 9.0 per cent of total exports of services from the UK in 2014" (DCMS 2016a). Throughout the late 1990s and 2000s, the creative industries were heralded as emblematic of a successful post-industrial Britain.

From its inception, the term "creative industries" was an invention of policymakers designed to benefit governance as opposed to the cultural sector. Rosamund Davies and Gauti Sigthorsson demonstrate that the process of categorising sectors of creative production under one organisational system came from a governmental drive to "estimate how many people work in the creative industries, how many businesses there are in each area, the export value of creative services from the UK, and how much the creative industries contribute to the gross value added (GVA) of the UK economy as a whole" $(2013,9)$. The function of grouping

\footnotetext{
${ }^{36}$ Each of the thirteen sectors are described through the following lenses of analysis: Industry Revenues, UK Market Size, Balance of Trade, Employment, Industry Structure, International Critical Acclaim, Secondary Economic Impact, Potential for Growth and Growing the Sector, and Issues for Consideration. The list demonstrates the economic categorisation that shapes the definition of the "creative industries". See DCMS "Creative Industries Mapping Documents" (1998).
} 
creative organisations and businesses together operates on a national level. At this scale, statistics show that the "creative industries" is the fastest growing sector of the British economy. In the introduction to the "Creative Industries Mapping Documents 2001", Chris Smith (then Secretary of State for the DCMS) declared that "the creative industries have moved from the fringes to the mainstream" $(2001,3)$. The concept remains popular among policymakers today, despite the zeal around the creative industries having waned somewhat since the global financial crisis in 2008. ${ }^{37}$ For example, a 2016 press release from the DCMS announced that "the UK's Creative Industries now contribute a staggering $£ 84$ billion a yearalmost $£ 10 \mathrm{~m}$ an hour-to our economy" (DCMS 2016b). Ed Vaizey (then acting Minister for Culture, Communications and Creative Industries) described the creative industries as "British magic dust" which "gives our country a unique edge". ${ }^{38}$ Such statements reveal that the creative industries are both financially and ideologically valuable to the state.

Work in the field of cultural studies and in the humanities has long critiqued the commodification of culture in these terms. ${ }^{39}$ Terry Flew argues that the creative industries are "a kind of 'Trojan Horse' through which to smuggle neoliberal discourses into the field" which "subvert the critical mission of cultural studies and related fields of humanities scholarship" $(2012,6)$. In addition, a significant body of work indicates that the perceived social and economic benefits of the creative industries are overinflated through their inclusion of technology and software data, which provides a positive skew on the calculation of profits and employment statistics. Flew argues that the "inclusion of the software sector in the creative industries artificially inflated their economic significance in order to align the arts to more high-powered 'information society' policy discourses" $(2012,13)$. Such amalgamations with Information Technology persist in valuation of the creative industries today, in 2014 "exports of services from the 'IT, software and computer services' was responsible for the largest proportion of service exports from the Creative Industries (44.6\%)" (DCMS 2016a). Therefore, the ways in which the creative industries are defined is crucial. Neil Garnham explores the effects of

\footnotetext{
${ }^{37}$ See O'Connor, J. (2010); Flew, T. (2012).

${ }^{38}$ Quoted in YouTube interview as part of a week-long digital event to raise awareness for the launch of the CREATE UK strategy in July 2014.

${ }^{39}$ For cultural studies see McRobbie, A. (1996); Harney, S. (2010). For critical humanities see Brown, W. (2005); Bourdieu, P. (1998); Gagnier, R. (2000).
} 
including technology in the Creative Industries first mapping documents. He argues that the inclusion of IT and software meant that the DCMS was able to secure more money because of perceived skills shortages in these areas. Garnham describes how "skill shortages in the ICT industries were a major drag on economic growth and relative competitiveness" (2005, 27). This was a key motivating force in the overall support of the creative industries. What is evident in the above history is the continued importance of management approaches in shaping cultural policy throughout the 1990s and that playing a game in which the rules were set out by policymakers has disadvantaged the creative sector in several distinct ways.

The legacy of NPM continues to exert its influence upon output-led values and works in tandem with the drive towards accountability inherent in the Modernising Government white paper, published under New Labour. Flew describes how the "association of creative industries with the modernisation project of Tony Blair's 'New Labour' was strong” $(2012,11)$. As culture came to be perceived as an industry throughout the 1990s and into the 2000s, artistic value has become tied to economic benefit. Anne Boddington et al. observe how this New Labour philosophy "conceived knowledge as a form of currency that could be shared, distributed and acquired" $(2013,6)$. Such framing devalues the intrinsic qualities of creative knowledge, seeing value only when they produce a currency or a commodity that can be exchanged. The implication of considering "knowledge as a form of currency" (6) speaks back to Bennett's observations about the Victorian museum and the Foucauldian "power to 'show and tell" $(1995,87)$. As seen in the Victorian museum, the contemporary museum is of equal interest to policymakers when thinking at a national level. However, unlike the imperialist nationalism in collections such as the British Museum's, today knowledge is most valuable in its potential for transference rather than as a discrete representative object to be owned and managed by the state. The value of cultural activity is measured by economic exchange; in the conception of culture as an industry, creative practices and organisations are transformed into valuable national assets within a global marketplace.

Despite the prevalence of critical misgivings about the rhetoric of the creative industries, there has been little change to the assessment mechanisms since the 1980s. A study conducted by the RAND Corporation details that "although many advocates of the arts believe intrinsic benefits are of primary importance, they are reluctant to introduce them into the policy discussion because they do not believe such ideas will resonate with 
most legislators and policymakers" (McCarthy et al. 2004, 37-8). Therefore, a reluctance of arts and humanities scholars and practitioners to engage in arguments concerning intrinsic value leads to a public debate that mischaracterises what they stand for. Currently, as opposed to a discussion about alternative values, the arts and culture sector largely conforms to funding requirements in offering justifications in the form of economic value. ${ }^{40}$ The economisation of arts funding criteria in the $1980 \mathrm{~s}$, demonstrates that cultural institutions are often reluctant to reject arguments that promote their wider societal value, albeit in solely economic terms. In “'Impact', 'Value' and 'Bad Economics': Making Sense of the Problem of Value in the Arts and Humanities", Belfiore argues that the language of the creative industries has been widely adopted because it "appears to offer a rhetorically powerful articulation of value and an attendant rationale for funding, critically able to win the approval of a Treasury department set on cutting public expenditure" $(2015,101)$. This conformity is problematic and ultimately leads to "the collapse of value into impact of the sort that lends itself to be expressed in monetary terms" (105). The rhetoric of the cultural sector reveals an "anxiety of justification" (105) that has emerged under the present conditions of assessment and valuation within the cultural sector, with a range of negative effects.

The above discussion has demonstrated the influence of the economic valuation upon the management of museums over the last thirty years. The influences of NPM within the cultural sector persist today. In light of this, I argue that the prioritisation of impact in higher education has been foreshadowed by the accountability agenda in the museum sector during the 1980s and 1990s. Attentiveness to the changes and challenges facing museums in the past and present provides humanities scholars with a set of debates that are historically rooted, extensively researched, and widely debated. They offer evidence from which to respond to the seemingly 'new' questions of the value facing the humanities. Considering the conclusions of Foucault's “Society Must Be Defended" lectures at the Collège de France, 1975-6, Bröckling et al. observe how

subjects are not merely effects of the exercise of power, but also possess selfwill and agency - this is already at work conceptually in the copresence of power and freedom in the idea of government. [...] Students being evaluated by professors, employees supervised by their superiors - all of them are

${ }^{40}$ See Bérubé, M. (2002); Parker, J. (2008); Belfiore, E. (2015). 
not merely objects of government, nor are they fully determined by technologies of control. Their manner of operating rather resembles a relay: in articulating themselves as subjects they take part in power relations, thus reproducing and transforming them. $(2011,14)$

This state of governance operates as a form of praxis, whereby those who are affected participate in their own negation. Intervening in this process requires individual agency, which is a liberal rather than a neoliberal trait. In our present moment, reclaiming a position that suggests that there is an alternative is challenging. With the benefit of the experience and critical argument from both Victorian debates and contemporary museum studies, this chapter now reconsiders the emergent mechanisms of assessment and accountability within higher education.

\subsection{PART III: REF-LeCTIONS FOR THE ACADEMic Humanities}

So far, this chapter has historicised and located changes to the valuation of humanities research within a wider narrative of cultural value in England by reflecting on accountability within the Victorian Museum and management of cultural policy in the 1980s. Tusa's complaint, discussed above, that "we have lost a vocabulary and an area of permitted public discourse where values are valued rather than costed" $(2000,29)$ is a clear precursor to Collini's lament that "economistic officialise" $(2009,19)$ has overrun the mechanisms of valuation within humanities departments. There are many correlations between the public cultural sector and the debates concerning the value of the humanities. This section explores four key lessons that can be taken from the above narrative concerning the management of museums, each of which contributes towards a clearer understanding of the present changes concerning impact assessment within higher education.

First, the discussion of the foundation of the British Museum identified how the interest in the public museum principally operated on a depersonalised scale, which was dictated by imperial interest in exhibitions of national power and an abstract, but largely unenforced, desire to use culture in order to civilise the lower classes. Second, analysis of the Victorian critique of turnstiles versus public use of museums opened up a debate concerning the limitations of economic measurement and revealed how ever granular metrics cannot accurately account for those values that resist quantification. Mechanisms of valuation that focus on outputs and impacts 
as indicators of value are identified as being insufficient. Third, close interpretation of the operation of New Public Management demonstrated the restriction on alternative values under neoliberal governance. Theories of governmentality expose how this control is enacted in the processes and mechanisms of the assessment criteria. Finally, within a cultural milieu dominated by the logic of the creative industries making an intrinsic argument for the value of the arts and humanities is increasingly difficult and at odds with social value debates. This section specifically negotiates recent changes surrounding impact in higher education with assistance from these considerations from the museum sector. In this way, the correspondences between the two sectors are made explicit and productively put to work.

\subsubsection{Reinforcing National Interests Within the Impact Agenda}

In an afterword to John Holmwood's A Manifesto for the Public University (2011) Sir Steve Smith, then President of Universities UK (UUK henceforth), acknowledges the economic preference of policymakers. Smith recounts that when facing the changes to higher education policy in 2009-10, "[UUK] felt the language of economics was the only language that would secure the prosperity of our universities and higher education institutions" (129). Smith admits that "we tailored a narrative that did not start with the universities and what might be good for them, but with the economy, and specifically with the best strategy to ensure future economic growth" (2011, 131). Reading such an admission, alongside the regretful comments of Anthony Field (see Sect. 2.3) concerning the "sad decline to quantifying arts in material terms" (Sinclair 1995, 129), offers a portentous vision for the future valuation of universities in England, as such conformity is seen to have severe consequences.

Further examples of institutional compliance to national economic narratives are widespread within universities and other educational bodies across the UK. The Arts and Humanities Research Council (AHRC) published an economic calculation of the value of their research funding in their "Leading the World: the Economic Impact of UK Arts and Humanities Research" report (2009). This was achieved by hiring a multinational professional services company, PricewaterhouseCoopers (PwC), who calculated that "for every $£ 1$ spent on research by the AHRC, the nation may derive as much as $£ 10$ of immediate benefit and another 
$£ 15-£ 20$ of long-term benefit" (3). Such comments evidence the perceived need for the academic humanities to conform to economic models of valuation. Ellen Hazelkorn describes the "shift from valuing intellectual pursuits-for-their-own-sake to measuring research outcomes, impact and relevance" $(2015,27)$. The intrinsic value of the humanities is disregarded in favour of a perspective that sees all degrees as instrumental and all certification as a subset of a national labour market demand.

\subsubsection{The Focus on Outputs and Impacts Misrepresents the Value of the Humanities}

Much like the initial changes to accountability in public museums, the decision to revise the REF developed out of policymaking discourse. Government reports and white papers published between 2006 and 2008 are testament to an increased attention to the economic potential of higher education. The conception of the REFs system was first highlighted in the pre-budget report "Investing in Britain's Potential: Building our LongTerm Future" (HMSO 2006a). Given the discussion in part two of this chapter, regarding the trends in NPM and the priorities of neoliberal governance, it should not be a surprise that the government's vision of the "long-term future" of higher education is couched in economic terms. The report states that "in order to optimise the economic impact of research, the new system will provide greater rewards for user-focused research" (HMSO 2006a, 58). The measurement of impact was to be numerically calculated. The "Science and Innovation Investment Framework 2004 - 2014" (HMSO 2006b) clearly outlines the "government's firm presumption" that "after the 2008 RAE the system for assessing research quality and allocating $\mathrm{QR}$ [quality related] funding from the DfES [Department for Education and Skills] will be mainly metrics-based" (10). ${ }^{41}$ The government's goal was for economically valuable research to be the priority of higher education and therefore the designed assessment criteria that defined value in metric terms.

\footnotetext{
${ }^{41}$ One could read much about the culture of efficiency in the reduction of the words "quality related" into the meaningless, but more concise, acronym "QR".
} 
In "Governing Culture: Legislators, Interpreters and Accountants" (2016) Claire Donovan and Dave O'Brien describe how "the initial proposal from the Treasury was to use a metrics-only approach to gauge the impact of university research upon the economy and industry" (28). Peer review and qualitative metrics were only re-introduced when "the metrics proposed, such as grants from business, and numbers of patents and spinout companies created, were found to be very low order measures of such impact" (28). This demonstrated, in simple terms, that the main business of higher education is not business. Donovan and O'Brien observe how "the proposed model also centred on the natural and physical sciences and so neglected the humanities, arts, and social sciences, and had little relevance for gauging the wider social, cultural and economic benefits of academic research" (28). As discussed in Chap. 3, policy favours STEM research, and so the frameworks to measure the value were largely based around scientific research. Donovan has extensively researched the changes in forms of evaluation metrics in higher education in England and in Australia. In "The Qualitative Future of Research Evaluation" (2007), she describes the "rise in the desire to evaluate the value of publicly funded research for 'end users' and industry, and the accompanying urge to construct quantitative measures to aid this assessment" (586). These measures do not organically emerge out of existing higher education assessment, but rather represent an imposed logic that is far from a natural fit.

Somewhat ironically, research to date that has most effectively evidenced the insufficiency of the REF has done so on financial grounds. The 2014 REF proved to be an expensive and time-consuming process for both universities and the governing body, HEFCE. ${ }^{42}$ Ben Martin describes that a problematic cycle of assessment is emerging:

as mechanisms fail to capture certain aspects of impact, so additions will be made to the assessment machinery, adding to the costs and the compliance burden, encouraging more 'game-playing', introducing more perverse incentives and generating more unintended consequences. (2011, 251)

The RAE is reported to have cost up to $£ 100$ million over each cycle. ${ }^{43}$ Martin argues that given the increased complexity of the REF "the costs (both direct and indirect) are likely to be greater now the impact

\footnotetext{
${ }^{42}$ See Martin, B. (2011); Hazelkorn, E. (2012); Stern, N. (2016).

${ }^{43}$ See Sastry and Bekhradnia (2006).
} 
assessment has been added to it" $(2011,251)$. It is reasonable to assume that the REF costs more than the RAE because HEFCE is running an entire peer review process alongside the additional calculation of impact. The REF press office reports that the 2014 cycle accounted for " 52,061 academic staff, 191,150 research outputs [and] 6,975 impact case studies" (REF 2014). These numbers represent a large administrative undertaking for each university department submitting research outputs and impact case studies. The Stern Review "Building on Success and Learning from Experience: An Independent Review of the Research Excellence Framework" (July 2016) confirms Martin's suspicion that the costs in undertaking the REF are high: "estimated at $£ 246 \mathrm{~m}$ for UK HE sector, [the REF costs are] considerably more than estimates for the 2008 framework which cost around $£ 66$ million" (45). In a Kafkaesque revelation, the costs associated with evaluating the research and generating its impact score, were greater than the combined economic value of all the research that was measured. The government acknowledges that the 2014 exercise was "not entirely successful" (Stern 2016, 45) given its cost. Stern expressed a desire to improve financial management but offers little hope for redressing the dominance of metric-based evaluation criteria. However, identifying the failure of the system to generate economic revenue is significant. The system that holds academics to economic account to account has not itself been held to account.

\subsection{3 "The System Does Not Speak for Me"}

In "Expertise, the Academy and the Governance of Cultural Policy" (2013) Philip Schlesinger asserts that the REF represents a "novel bureaucratic imperative [that] has added a distinctive calculation to activities that have never before been expressly and principally driven by the need to increase university research funding or to secure collective prestige" (33). Schlesinger identifies how these "distinctive calculations" come to shape the actions of the assessed. As the above discussion of New Public Management explored, the actions and processes of governance have a significant effect on the result. In World-Literature in the Context of Combined and Uneven Development (2015) Sharon Deckard et al. define the REF as being a "top-down, state-imposed scheme, centralised and massively bureaucratic" which has been seen to have "deleterious effects on the scope, ambition, originality and independence of humanities scholarship, especially among younger scholars" (2) whose experience is a kind 
of neoliberal nativism. The emotive language of Schlesinger and Deckard et al. exposes a strong objection to the integration of business and management methodologies into the assessment of the value of the academic humanities.

An individual scholar may have a set of personal and academic aspirations that are at odds with the values that the bureaucratic impact agenda counts as being valuable. This problem not only effects departmental strategy but also has a range of impacts on the locus of an individual: their research choices, employment opportunities, and financial security. ${ }^{44}$ During 2011-13 Jennifer Chubb and Richard Watermeyer conducted a series of semi-structured interviews with senior academics in the UK and Australia on their perceptions regarding impact. They published their findings in a 2017 article, which identified how "sensationaliz[ing] and embellish[ing] impact claims was seen to have become a normalized and necessary, if regretful, aspect of academic culture and arguably par for the course in applying for competitive research funds" $(2017,2365)$. To return to Heidegger's idea of language as a house of being, it is clear that in adopting such limited tools to think with, academia becomes subservient to market forces. Although many of the academics were sceptical of the validity of metric evaluation, Chubb and Watermeyer note that the "preoccupation with performing public accountability occurs with the neglect of self-accountability" (2017, 2369 italics original). In other words, academics are required to conform to and visibly celebrate the required frameworks in order to subsist, even if such performances go against their personal beliefs. Resignation in the face of systemic change is understandable but does not provide any means of resistance to the erosion of the value of research. Chubb and Watermeyer's interviews chart this "sense of individual academics shouting into an abyss" (2368) when offering criticism of the REF's metric-based demands. They also noted the clear incentives for individuals to avoid critiquing the system that measures their value to their employer. Such a situation directly parallels the example of museum funding during the 1980s. Individuals do not agree with the valuation system, however, they feel disempowered to make a change because of the regulatory nature of the system. Cris Shore describes these

\footnotetext{
${ }^{44}$ In addition, impact on individual scholars is unevenly distributed. Categories such as gender, class, and race, exacerbate unequal distributions of privilege. See Ryan-Flood and Gill (2010); Rollock, N. (2013).
} 
pressures in "Audit Culture and Illiberal Governance: Universities and the Politics of Accountability" (2008), arguing that:

most academics may know that faith in audit (like faith in 'the market') is not borne out by its actual effectiveness in doing what it claims, but [realise that] the structures, careers and interests that have been forged as a result of these audit systems have created a powerful disincentive for individuals to rock the boat publicly. (292)

This encapsulates the effectiveness of neoliberalism, in removing the grounds for its critique: the individual benefit of not speaking up acts against a collective social benefit. Donovan highlights how within higher education "these metrics are in their infancy" $(2007,586)$ and argues that the full extent of the changes are yet to be realised. Given the novelty of these proposals, scholars have time to alter and challenge the underlying assumptions that misrepresent the work and values of the humanities.

\subsubsection{The Humanities and the Creative Industries}

The ways in which higher education, perhaps above and beyond the public cultural sector, is enmeshed with the idea of the creative industries, is most crudely articulated in the national supply and demand quota for graduates. The following discussion provides a further body of evidence to back up the claims established throughout this book, that data sets are malleable objects often used irresponsibly by policymakers to portray the appearance of economic progress.

In Creative Industries: Focus On Employment (June 2015) the DCMS reported that "one in every six jobs in the UK held by graduates in 2014 was in the Creative Economy" $(2015,7)$. Figure 5.3 demonstrates that for the sectors within the creative economy, the number of graduates is significantly higher than the UK average. Alongside the DCMS, other higher education bodies, such as the Higher Education Careers Service Unit (HECSU henceforth), have used employment statistics that affirm the value of the arts and humanities degrees by interpreting this correlation as causal and arguing that higher education provides the required skillsets for employment in the creative industries.

However, the recent HECSU report "What Do Graduates Do?" (Logan et al. 2016) describes how "whilst the creative arts subjects are 


\begin{tabular}{|c|c|c|c|c|c|c|}
\hline & 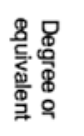 & 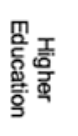 & 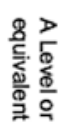 & 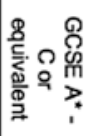 & 옥 & 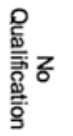 \\
\hline Advertising and marketing & $59.3 \%$ & $7.0 \%$ & $15.0 \%$ & $12.7 \%$ & $2.7 \%$ & $2.5 \%$ \\
\hline Architecture & $74.6 \%$ & $9.6 \%$ & $6.5 \%$ & $6.2 \%$ & $1.5 \%$ & $0.8 \%$ \\
\hline Crafts & $17.9 \%$ & $6.4 \%$ & $28.1 \%$ & $23.9 \%$ & $9.6 \%$ & $11.5 \%$ \\
\hline Design: product, graphic and fashion design & $46.6 \%$ & $12.9 \%$ & $22.3 \%$ & $10.5 \%$ & $3.1 \%$ & $2.6 \%$ \\
\hline Film, TV, video, radio and photography & $52.3 \%$ & $10.9 \%$ & $18.1 \%$ & $11.8 \%$ & $3.6 \%$ & $2.4 \%$ \\
\hline IT, software and computer services & $64.7 \%$ & $8.9 \%$ & $14.3 \%$ & $9.0 \%$ & $1.8 \%$ & $0.7 \%$ \\
\hline Museums, galleries and libraries & $61.3 \%$ & $6.6 \%$ & $13.4 \%$ & $11.7 \%$ & $5.5 \%$ & $1.0 \%$ \\
\hline Music, performing and visual arts & $58.4 \%$ & $10.5 \%$ & $14.9 \%$ & $10.7 \%$ & $2.7 \%$ & $2.3 \%$ \\
\hline Publishing & $60.5 \%$ & $8.2 \%$ & $13.7 \%$ & $10.4 \%$ & $4.5 \%$ & $2.4 \%$ \\
\hline Creative Economy Average & $58.8 \%$ & $9.1 \%$ & $15.5 \%$ & $10.9 \%$ & $3.0 \%$ & $2.0 \%$ \\
\hline UK Economy Average & $31.8 \%$ & $9.7 \%$ & $23.2 \%$ & $19.9 \%$ & $8.4 \%$ & $5.5 \%$ \\
\hline
\end{tabular}

Fig. 5.3 Proportion of jobs by highest level of qualification in the Creative Economy in 2014. (Source: DCMS, 15 June 2015)

linked to the creative industries, there are fewer clear vocational links between the arts and humanities and the labour market" (32). The HECSU study notes that a greater percentage of creative arts graduates working within the creative industries studied subjects such as Design or Performing Arts as opposed to humanities subjects such as History, English, or Languages. ${ }^{45}$ Therefore, such statistics wilfully mischaracterise the relationship between undergraduate degrees and the national labour market. Consequently, scholars must challenge the uses of statistics and draw attention to the ideological positioning of such data collection. In addition, this cross-disciplinary data, which makes use of percentage comparisons, obscures how far more students study the humanities than the creative arts. Therefore, in terms of raw numbers of employees, there are more graduates with a BA in English working within the creative industries than graduates with a background in the Fine Arts, despite the headline of the HECSU report. According to the HESCU 2016 figures, whilst only $9.5 \%$ of the surveyed English graduates are employed as "Arts, Design

${ }^{45}$ Of the HESCU report participants $42.9 \%$ of Design students and $29.5 \%$ of Performing Arts students were employed as Arts, Design and Media professionals, while only $3.5 \%$ of History, $6.8 \%$ of Languages students, and $9.5 \%$ of English graduates found employment in this sector. See 34-42. 
and Media Professionals", this equals 526 people. There are, an impressive sounding, 24\% of Fine Arts respondents working in the same sector, however, this represents only 445 individuals. As seen in the data manipulation of ICT skillsets above, in the foundation of the creative industries (Sect. 2.4), these HECSU statistics reveal a national interest in the commercialisation of the creative arts. The headline reads: "total employment in the creative industries increased by $5.5 \%$ between 2013 and 2014, to 1.8 million jobs" (Logan et al. 2016, 32). With the creative industries heralded as a national success story and with the sector being filled with half of arts and humanities graduates, it is unsurprising that alternative modes of valuation of culture are under threat.

That a significant number of arts and humanities graduates find employment in the creative industries in the UK is not intrinsically negative for the academic humanities. However, it is troubling that within wider public discourse there are very few instances of government officials giving any credibility to the idea of an intrinsic value of the arts and humanities. In terms of research assessment culture, the concern of instrumentalism is equally applicable. The expansion of economically focused metrics into the REF mirrors the increasing prioritisation of data concerning graduate employment in the creative industries. There is, however, a significant difference between employment metrics and the evaluation of academic research in the REF. Whilst some students do attend to university solely in order to get a job, making money rarely primarily motivates research in the humanities.

\subsection{Part IV: A Response from the Humanities}

In an Arts and Humanities in Higher Education special issue on the "Public Value of Arts and Humanities Research" (2015) Paul Benneworth identifies how "in acquiescing to the demands from policy-makers under pressure for clarity and simplicity, a sense of nuance, ambivalence, and tension has been lost from these public debates around the public value of arts and humanities research" (5). Both in terms of the configuration of humanities graduates as national assets and the reframing of the value of research in terms of economic profit and impact, it is clear that the narratives of neoliberal governance have significant effects throughout the university. The final section of this chapter addresses how scholars have begun to respond to the changes in impact assessment, and outlines future directions for research in this vital area of debate. 
To date, humanities research into the "impact of impact" has been largely informal, presented in comment articles, online blogs, discussions at symposia, and conference plenaries. ${ }^{46}$ Only a handful of academic journals have dedicated special issues to the rise of impact agendas within the humanities. ${ }^{47}$ I have previously explored how the majority of research that analyses the implications of research assessment mechanisms for the humanities has been developed in the social sciences (Bulaitis 2017). ${ }^{48}$ In their 2012 paper, "Indicators for Research Quality in the Humanities: Opportunities and Limitations", Michael Ochsner et al. detail how researchers have sought to use interviews, bibliometric, and scientometric literature to address the challenges of capturing the value of the humanities within present assessment frameworks. They highlight that there is a "missing link between indicators and humanities scholars' notions of quality" (1). This reinforces the above discussion, which concluded that the indicators of policy are disconnected from the work that scholars value. Ochsner et al. conclude that "bottom-up processes" $(2012,5)$ are required to redress the difficulty in assessing the value of teaching and research. A "bottom-up" approach, aims to give scholars a voice in the construction of quality indicators. Ochsner et al. suggest that an engagement with specific disciplinary needs may offer a productive solution to the present dissonance between the assessed and their assessment. As part of the 2017 Palgrave Communications series on The Future of Research Assessment, Ochsner et al. developed their 2012 findings to highlight recent European initiatives that have sought to "assess SSH [Social Science and Humanities] research with its own approaches instead of applying and adjusting the methods developed for and in the natural and life sciences" (9). Their findings point to the importance of scholars attending to research assessment processes in ways that reflect their disciplinary position. This final section considers the qualities of a humanities-centred contribution. In doing so, it explores the effectiveness of a "bottom up" $(2012,5)$ approach to the future of research assessment in the humanities, by using the basic tenets of humanities research to articulate the full implications of the inclusion of impact within research assessment frameworks.

${ }^{46}$ For blogs and comment, see Anderson, R. (2010); Stilgoe, J. (2014); Lears, J. (2015). For conferences, see Hewison, R. (2011); Schlesinger, P. (2014).

${ }^{47}$ See Arts and Humanities in Higher Education (2015).

${ }^{48}$ See Oancea \& Furlong (2007); Bakioglu \& Kurnaz (2009). 
Humanities scholars have only just begun to explore the full effects of the REF's assessment approach. ${ }^{49}$ In The Value of the Humanities, Helen Small identifies in defining the work of the humanities, a common scholarly approach is "individual response (its content and its style)" (2013, 57). Critiques that contest the hegemonic agendas of impact at this scale are incompatible with market-led neoliberal structures, but this need not be a flaw. Many individual humanities scholars have personally critiqued the insufficiency of the REF. For example, speaking at a conference at the University of Sheffield, 5 May 2011, Robert Hewison observes that "whoever wrote the documents for the REF, does not appear to have been trained in the humanities" (2011). Hewison's highlighting "whoever wrote" is a reminder of the human(ity) behind the written word of policy. The language of the REF replicates the economism inherent in present policymaking. Hewison identifies how such a restrictive framework is at odds with a notion of humanities scholarship that is considered and existentially open-ended. He continues, describing how the REF submission advice is written in the "unlovely technocratic language of generic templates, impact sub-profiles, and submitted units, which turn out to be people like me, who put 30 years [of] work into a single book" (2011). The conflation of the individual academic into a "submitted unit" draws attention to the disregard of the specific people working within the professions.

Similarly to Hewison, in a closing address of the CREATe All Hands Conference in Glasgow, 16 September 2014, Schlesinger commented: "our research now has to meet impact criteria that were invented for accountability rather than public intellectuality" (2014). Schlesinger argues that the assessment criterion prioritises the actions of bureaucratic accountability above an engagement with people, through public engagement. The REF system rewards that research that can be counted and accounted for, which produces a bias towards research whose results are economically rather than socially beneficial. Hewison's and Schlesinger's appraisals of the REF are, to my mind, entirely correct. Work within the social sciences which has evidenced that humanities scholars recognise alternative values in their work. ${ }^{50}$ For example "being a courageous

${ }^{49}$ In 2017, Palgrave Communications launched an open-access special issue on the "Future of Research Assessment" which provides some valuable contributions to this emergent field of debate.

${ }^{50}$ See Hemlin, S. (1996); Guetzkow et al. (2004); Ochsner et al. (2017). 
risk-taker with authentic intellectual interests" (Guetzkow et al. 2004, 206 ) is highlighted in a study of the concept of originality within the humanities and social sciences. Humanities scholars need to build upon such evidence, in order to provide an alternative language of value that speaks up for that which the REF neglects.

Given the conflation of economic value and cultural value in the dominant context of the cultural industries, it is unsurprising that scholars are resistant to engage with value narratives. Michael Bérubé describes how academics "tend to regard self-justification as a dubious enterprise best left to the writers of admissions brochures and back-patting liberal-arts mission statements" $(2002,25)$. He likens the writers of brochures (who doubtless are, themselves, humanities graduates employed within the creative industries) to sheep. ${ }^{51} \mathrm{He}$ imitates: "the Humanities teach us what it is to be human, the Arts deepen our spirit, the Humanities preserve our common cultural heritage, bleat, bleat, bleat" (25). This awkward impersonation exposes the difficulty of avoiding clichés when publicly communicating the value of humanities scholarship. However, the representations of fictional humanities departments in Chap. 4 demonstrate the possibility for alternative languages of value beyond bland marketing clichés and other stereotypes. The individual testimonies of Hewison and Schlesinger, above, demonstrate that humanities scholars are resistant to engage in the processes of marketing, and avoid speaking "economistic officialise" (Collini 2009, 19). Their testimonies remind scholars that the articulation of value need not equate to a marketing pitch. Although only on an individual scale, these critiques reject the language that seeks to define their academic work. Mark Fisher's Capitalist Realism concludes by calling for such small acts of resistance as "even glimmers of alternative political and economic possibilities can have disproportionately great effect" $(2009,80-1)$. The agency that is involved in articulating "the system does not speak for me" is perhaps more powerful than has previously been recognised.

\footnotetext{
${ }^{51}$ Incidentally, an ovine metaphor is also used by William Deresiewicz in his work on neoliberalism within the US universities: Excellent Sheep: The Miseducation of the American Elite (2014).
} 


\subsection{Conclusion}

Neoliberal governance in higher education in England represents a challenge to long-held ideals of the value of universities. As I have shown throughout this book, the processes of marketisation and economic determination dominate the language of evidence and justification in higher education. Within such an environment, it is important to work towards a positive valuation of the humanities as opposed to a merely reactive one that reincorporates resistance to neoliberalism into the language of educational value. It is the responsibility of humanities scholars to ensure that alternative values and accounts are pursued. Those working in the humanities should be accountable. Accountable to ourselves, to society and to those members of society that are systemically unable to speak out for themselves, but these are not criteria that are important to the REF. Schlesinger notes that the

dominant discourse celebrates only efficacious knowledge exchange. This banishes any serious consideration of knowledge resistance. Consequently, a major challenge will be to find novel ways of ensuring that inconvenient truths circulate with significant effect in the public domain. $(2013,34)$

That the REF denies ground for its critique through requiring faculty participation is one of the major challenges facing the humanities. Expressions of individual defences are all too easily dismissed as being inconsequential when contested by large-scale economic and national benefits. However, humanities scholars need to articulate alternative values at the level of the individual in an era of marketisation.

This reclamation of agency and recognition of the value in cultivating of a society of individuals is one last lesson we can take from Victorian notions of a liberal education. I am not suggesting the anachronistic application of one epoch's ideas and ideals onto another, but I am arguing for the benefit in reviving a mode of thinking that allows for greater agency of individual thought and action. Returning to the fundamental debates about access to higher education, accountability, and the economy offers the contemporary humanities scholar a useful set of considerations.

Like many who argued for the value of a liberal education, Matthew Arnold repeatedly and unashamedly sought to understand the spirit of humanity as opposed to "an outward set of circumstances" $(1869,62)$. In the present moment, a rejection of the idea that "every opinion, no matter 
how eccentric or ill-grounded, [could] pass itself off as the equal of any other" (Collini 2008, 59) is useful to hold in mind. To date, research in the social sciences has only got so far in imagining how this recognition of disciplinary distinction might translate into reformed assessment criteria, and greater contributions are required from the humanities, who are best able to communicate this specialist set of concerns.

I argue that in the contemporary context of higher education in England, no one can better articulate the value of the humanities than those working within it. Therefore, it is the responsibility of scholars to continue to read, to historically interpret, and to interrogate cultural policy that seeks to define them. This book provides a contribution to the development of such an approach, but further research is urgently required in order to better understand and articulate the creation of cultural value and the mechanisms that drive its assessment. Deconstructing the mechanisms and processes of government unmasks a uniform and omnipresent policy showing it to be a historically contingent, malleable, and imperfect piece of political machinery. This chapter has outlined a long history of public accountability in the culture sector from the establishment of the Victorian public museum to the formation of neoliberal assessment criteria. Throughout, there have been intersections between individual and national interests. Sloane's aspiration for a public museum was transformed into a bureaucratic and nationalistic endeavour at the hands of the museum's trustees. The economisation of the value of the Arts Council lies with Anthony Field, and his colleagues, accepting that there was no alternative but to conform to justification and accountability. Steve Smith's admission that Universities UK decided to defend the value of universities in economic terms in the recent reforms demonstrates a similar culture of acceptance.

However, in articulating the value of the humanities, economic value does not represent who we are or the merit of our work. Instead of arguing economically, a revival of a critical disposition proves to be a useful methodological tool through which to construct a socially and historically informed assessment of mechanisms for attributing value. The expansion of neoliberal management metrics and the enduring centrality of the creative industries is testimony to the powerful effects of economic value. However, this chapter has demonstrated how in a critique of phenomena seeking to be perceived as permanent, an understanding of how the processes of value-construction operate aids in actions to denaturalise, contest, and resist. 


\section{BIBLIOGRAPHY}

A Member of the University of Cambridge. 1823. Letter to the Editor. The Times, October 10, 2.

Adorno, Theodor W. 1960. Culture and Administration. In The Culture Industry: Selected Essays on Mass Culture, ed. J.M. Bernstein. [2001], 2nd ed., 107-131. New York: Routledge.

Aguirre, Robert. 2005. Informal Empire: Mexico and Central America in Victorian Culture. Minneapolis: University of Minnesota Press.

AHRC. 2009. Leading the World: The Economic Impact of UK Arts and Humanities Research. The UK Arts and Humanities Research Council. Accessed 12 Nov 2016, via www.ahrc.ac.uk/documents/publications/leading-theworld/

Anderson, Amanda. 2005. Victorian Studies and the Two Modernities. Victorian Studies 47 (2): 195-203.

Anderson, Robert. 2010. The 'Idea of a University' Today. History \& Policy Online, March 1, Accessed 20 June 2017, via www.historyandpolicy.org/policy-papers/papers/the-idea-of-a-university-today

Antiquarius. 1823. Letter to the Editor. The Times, October 23, 3.

Arnold, Matthew. 1869. Culture and Anarchy. In Culture and Anarchy and Other Writings.. [1993], ed. Stefan Collini, 53-187. Cambridge: Cambridge University Press.

Arts and Humanities in Higher Education. 2015. Forum on the Public Value of Arts and Humanities Research. Artsand Humanities in Higher Education 14 (1).

Arts Council England. Why Culture Matters. Arts Council England website. Accessed 4 July 2016, via www.artscouncil.org.uk/why-culture-matters/ case-art-and-culture

Bakhshi, Hasan, Alan Freeman, and Graham Hitchen. 2009. Measuring Intrinsic Value How to Stop Worrying and Love Economics. Accessed 30 Aug 2016, via www.missionmodelsmoney.org.uk/sites/default/files/23974660-MeasuringIntrinsic-Value-Hasan-Bakhshi-Alan-Freeman-Graham-Hitchen-2009_0_0.pdf

Bakioglu, Ayşen, and Özlem Kurnaz. 2009. Quality Criteria of Research Perceived by Academics in Social Sciences at Higher Education. US-China Education Review 6 (3): 1-13.

Barrett, Jennifer. 2012. Museums and the Public Sphere. Oxford: Wiley-Blackwell. Barringer, Tim. 2006. Victorian Culture and the Museum: Before and After the White Cube. Journal of Victorian Culture 11 (1): 133-145.

Barzelay, Michael. 2002. Origins of the New Public Management: An International View from Public Administration/Political Science. In McLaughlin, K., Osborne, S.P. and E. Ferlie (eds). New Public Management: Current Trends and Future Prospects. London: Routledge, 15-33. 
Belfiore, Eleonora. 2015. 'Impact', 'Value' and 'Bad Economics': Making Sense of the Problem of Value in the Arts and Humanities. Arts and Humanities in Higher Education 14 (1): 95-110.

Belfiore, Eleonora, and Oliver Bennett. 2008. The Social Impact of the Arts: An Intellectual History. Basingstoke: Palgrave.

Bennett, Toby. 1992. Putting Policy into Cultural Studies. In Cultural Studies, ed. Lawrence Grossberg, Cary Nelson, and Paula Treichler, 23-37. London: Routledge.

- 1995. The Birth of the Museum: History, Theory, Politics. New York: Routledge.

Benneworth, Paul. 2015. Putting Impact into Context: The Janus Face of the Public Value of Arts and Humanities Research. Arts and Humanities in Higher Education 14 (1): 3-8.

Bérubé, Michael. 2002. The Utility of the Arts and Humanities. Arts and Humanities in Higher Education 2 (1): 23-40.

Billington, Michael. 2013. Margaret Thatcher Casts a Long Shadow Over Theatre and the Arts. The Guardian. April 8, Accessed 10 June 2016, via www.theguardian.com/stage/2013/apr/08/margaret-thatcher-long-shadow-theatre

Black, Barbara J. 2000. On Exhibit: Victorians and Their Museums. Charlottesville: University of Virginia.

Blair, Tony. 1999. Modernising Government. White Paper, Cm. 4310, London: HMSO.

Boddington, Anne, Jos Boys, and Catherine Speight, eds. 2013. Museums and Higher Education Working Together: Challenges and Opportunities. Farnham: Ashgate.

Bonython, Elizabeth, and Anthony Burton. 2003. The Great Exhibitor: The Life and Work of Henry Cole. London: V\&A.

Bourdieu, Pierre. 1998. A Reasoned Utopia and Economic Fatalism. New Left Review 227: 125-130.

Bozeman, Barry. 2007. Public Values and Public Interest. Washington, DC: Georgetown University Press.

Bradley, Ben. 2006. Two Concepts of Intrinsic Value. Ethic Theory Moral Practice. 9 (2): 111-130.

British Library, Department of Manuscripts. n.d. Thomas Birch, A Collection of Papers Relating to the Establishment and Government of the British Museum,. Add. MS 4,449 fol.115 and fols. 118-120.

British Library, Department of Manuscripts, Ward, John. 1757. Preamble to the Statutes and Rules, 1757 Ward, Papers relating to the British Museum, Add. MS 6179, folios 18-25.

British Museum. 2017. Accessing Enlightenment. British Museum Study Guide. Accessed 16 January 2018, via www.britishmuseum.org/pdf/British\%20 Museum\%20Study\%20Pack\%20Accessing\%20Enlightenment.pdf 
Bröckling, Ulrich, Susanne Krasmann, and Thomas Lemke. 2011. Governmentality: Current Issues and Future Challenges. New York: Routledge.

Brown, Wendy. 2005. Neo-Liberalism and the End of Liberal Democracy. In Edgeworks: Critical Essays on Knowledge and Production. Princeton: Princeton University Press.

Bulaitis, Zoe. (2017). Measuring impact in the humanities: Learning from accountability and economics in a contemporary history of cultural value. Palgrave Communications, 3 (1). Accessible via www.nature.com/articles/ s41599-017-0002-7.pdf

Cartwright, Alastair. 2011. Arts and the Cuts Part I: Arts on the Frontline. Counterfire, February 14, Accessed 13 Aug 2016, via www.counterfire.org/ arts-and-the-cuts/10138-arts-and-the-cuts-part-i-arts-on-the-frontline

Cash, Derek. 2002. Access to Museum Culture: The British Museum from 1753 to 1836. British Museum Occasional Paper (No. 133). London: British Museum.

Chubb, Jennifer, and Richard Watermeyer. 2017. Artifice or Integrity in the Marketization of Research Impact? Investigating the Moral Economy of (Pathways to) Impact Statements Within Research Funding Proposals in the UK and Australia. Studies in Higher Education 42 (2): 2360-2372.

Clark, A. 1991. Understanding the Contract Culture o Performance Measurement in the Arts. London: Centre for Leisure and Tourism Studies.

Clarke, Henry G. 1843-56. The British Museum: A Handbook Guide for Visitors. London, (successive editions).

Collini, Stefan. 2008. Matthew Arnold: A Critical Portrait. Oxford: Clarendon Press.

- 2009. Impact on Humanities: Researchers Must Take a Stand Now or Be Judged and Rewarded as Salesmen. Times Literary Supplement, November $13,18-19$.

Crary, Jonathan. 1990. Techniques of the Observer: On Vision and Modernity in the Nineteenth Century. Cambridge, MA: The MIT Press.

Cressy, David. 1980. Literacy and the Social Order. Cambridge: Cambridge University Press.

DCMS (Department for Culture, Media and Sport). 1998. Creative Industries Mapping Documents. April 9, Department for Culture, Media and Sport. Accessed 30 July 2016, via www.gov.uk/government/publications/ creative-industries-mapping-documents-1998

- 2001. Creative Industries Mapping Documents 2001. April 9, Department for Culture, Media and Sport. Accessed 30 July 2016, via www.gov.uk/government/publications/creative-industries-mapping-documents-2001

- 2015. Creative Industries: Focus on Employment. June, Department of Culture, Media and Sport. Accessed 17 Nov 2016, via www.gov.uk/government/uploads/system/uploads/attachment_data/file/439714/Annex_C_-_ Creative_Industries_Focus_on_Employment_2015.pdf 
. 2016a. Creative Industries: 2016 Focus On. June 20, Department of Culture, Music and Sport. Accessed 3 Aug 2016, via www.gov.uk/government/statistics/creative-industries-2016-focus-on

- 2016b. What a Performance! Stellar Employment Boom Continues for the UK's Creative Industries. July 4, Department of Culture, Music and Sport. Accessed 7 July 2016, via www.gov.uk/government/news/what-a-performancestellar-employment-boom-continues-for-the-uks-creative-industries

Deckard, Sharon, Nicholas Lawrence, Neil Lazarus, Graeme Macdonald, Upamanyu Pablo Mukherjee, Benita Parry, and Stephen Shapiro. 2015. Combined and Uneven Development: Towards a New Theory of World-Literature. Liverpool: Liverpool University Press.

Deresiewicz, William. 2014. Excellent Sheep: The Miseducation of the American Elite and the Way to a Meaningful Life. New York: Free Press.

Donovan, Claire. 2007. The Qualitative Future of Research Evaluation. Science and Public Policy 34 (8): 585-597.

Donovan, Claire, and Dave O'Brien. 2016. Governing Culture: Legislators, Interpreters and Accountants. Critical Perspectives on Accounting 37: 24-34.

Drakeman, Donald. 2016. Why We Need the Humanities: Life Science, Law and the Common Good. Basingstoke: Palgrave Macmillan.

Fisher, Mark. 2009. Capitalist Realism: Is There No Alternative? Winchester: Zero Books.

Flew, Terry. 2012. The Creative Industries: Culture and Policy. London: Sage.

Foucault, Michel. 1975. Discipline and Punish: The Birth of the Prison. Trans. Alan Sheridan [1995]. New York: Vintage.

- 1977-8. Security, Territory, Population: Lectures at the Collège de France 1977-1978. Trans. Graham Burchell 2007. Basingstoke: Palgrave Macmillan.

- 1979. Governmentality. Trans. Rosi Braidotti. Ideology \& Consciousness 6: 5-21.

Frow, John. 1999. Cultural Studies and the Neoliberal Imagination. Yale Journal of Criticism 12 (2): 424-430.

Gagnier, Regenia. 2000. The Insatiability of Human Wants: Economics and Aesthetics in Market Society. Chicago: University of Chicago Press.

Garnham, Neil. 2005. From Cultural to Creative Industries. International Journal of Cultural Policy 11 (1): 15-29.

Gibbons, Michael, Camille Limoges, Helga Nowotny, Simon Schwartzman, Peter Scott, and Martin Trow. 1994. The New Production of Knowledge: The Dynamics of Science and Research in Contemporary Societies. London: Sage.

Gillard, Derek. 2011. Chapter 3: 1860-1900 Class Divisions. Accessed via www. educationengland.org.uk/history

Graham, Hugh Davis, and Nancy Diamond. 1997. The Rise of American Research Universities: Elites and Challengers in the Post-War Era. Baltimore: John Hopkins University Press. 
Greenwood, Thomas. 1888. Why Should Every Town Have a Museum? Museums and Art Galleries. London: Simkin, Marshall and Company.

Guetzkow, Joshua, Michèle Lamont, and Grégoire Mallard. 2004. What Is Originality in the Humanities and the Social Sciences? American Sociological Review 69 (2): 190-212.

Hadley, Elaine. 2005. On a Darkling Plain: Victorian Liberalism and the Fantasy of Agency. Victorian Studies 48 (1): 92-102.

Hallett, Tim. 2010. The Myth Incarnate: Recoupling Processes, Turmoil, and Inhabited Institutions in an Urban Elementary School. American Sociological Review 75 (1): 52-74.

Halsey, A.H. 1997. Trends in Access and Equity in Higher Education: Britain in International Perspective. In Education, Culture, Economy and Society, ed. A.H. Halsey, Hugh Lauder, Phillip Brown, and Amy Stuart Wells. Oxford: Oxford University Press.

Hansard. 1821. Mr Lennard. British Museum. HC Deb vol. 4 cols. 723-6, February 16, Accessed 2 Jan 2018, via hansard.millbanksystems.com/commons/1821/feb/16/british-museum\#column_724

- 1821. Mr Grey Bennett. British Museum. HC Deb vol. 10 col. 1467. March 29, 1824. Accessed 15 Jan 2018, via hansard.millbanksystems.com/ commons/1824/mar/29/british-museum

- 1821. Lord Althrop. British Museum. HC Deb vol. 16 col. 1004, March 25, 1833. Accessed 3 Jan 2018, via hansard.millbanksystems.com/commons $/ 1833 / \mathrm{mar} / 25 /$ british-museum

- 1836a. Mr Ewart. British Museum. HC Debate vol. 31 cols. 308-12. February 11, Accessed 3 Jan 2017, via hansard.millbanksystems.com/commons/1836/feb/11/the-british-museum

- 1836b. Mr Hume. Supply. - Miscellaneous Estimates. HC Deb vol. 33 cols. 1155-68. May 30, Accessed 12 Aug 2017, via hansard.millbanksystems. com/commons/1836/may/30/supply-miscellaneous-estimates\#S3V0033P0_ 18360530_HOC_50

Harney, Stefano. 2010. Creative Industries Debate - Unfinished Business: Labour, Management, and the Creative Industries. Cultural Studies 24 (3): 431-444.

Harpham, Geoffrey Galt. 2011. The Humanities and the Dream of America. Chicago: Chicago University Press.

Hartley, John. 2005. Creative Industries. Oxford: Blackwell.

Hazelkorn, Ellen. 2012. Measuring Value: Societal Benefits of Research. The Chronicle of Higher Education. August 15, Accessed 13 Dec 2016, via www. chronicle.com/blogs/worldwise/measuring-value-societal-benefits-ofresearch $/ 30179$

2015. Making an Impact: New Directions for Arts and Humanities. Arts and Humanities in Higher Education 14 (1): 25-44.

HEFCE. 2011. Assessment Framework and Guidance on Submissions. Research Excellence Framework. Accessed 12 Nov 2016, via www.ref.ac.uk/media/ref/ 
content/pub/assessmentframeworkandguidanceonsubmissions/GOS\%20 including\%20addendum.pdf

- 2014. REF: Key Facts. REF2014 Website, December, Accessed 28 May 2016, via www.ref.ac.uk/2014/pubs/keyfacts/

- 2017. Initial Decisions on the Research Excellence Framework 2021. HEFCE. September, Accessed 20 Nov 2017, via www.hefce.ac.uk/media/ HEFCE,2014/Content/Pubs/Independentresearch/2017/REF,201701/ REF2017_01.pdf

Heidegger, Martin. 1946. Letter on Humanism. Basic Writings. Edited David Farrell Krell with a Foreword By Carman Taylor. London: Routledge Classics, 2011, pp. 141-182.

Hemlin, Sven. 1993. Scientific Quality in the Eyes of the Scientist. A Questionnaire Study. Scientometrics 27 (1): 3-18.

Hewison, Robert. 2011. The Value of the Arts and Humanities in the 21st Century. May 5, University of Sheffield, Panel Discussion. Accessed 3 February 2014, via www.sheffield.ac.uk/faculty/arts-and-humanities/value-of-arts

Hillman, Nick. 2016. The Coalition's Higher Education Reforms in England. Oxford Review of Education 42 (3): 330-345.

HMSO. 1993. Realising Our Potential: A Strategy for Science, Engineering and Technology. Cm2250, London: HMSO.

- 1999. Modernising Government. White Paper, Cm. 4310, London: HMSO.

- 2006a. Investing in Britain's Potential: Building Our Long-Term Future. Pre-Budget Report. London: HMSO.

. 2006b. Science and Innovation Investment Framework 2004-2014: Next Steps. March, London: HMSO.

Holden, John. 2004. Capturing Cultural Value: How Culture Has Become a Tool of Government Policy. London: DEMOS.

Holmwood, John, ed. 2011. A Manifesto for the Public University. London: Bloomsbury Academic.

Hood, Christopher. 1991. A New Public Management for All Seasons? Public Administration 69: 3-19.

Hudson, Kenneth. 1975. A Social History of Museums: What the Visitors Thought. London: Springer.

Hume, Robert D. 2015. The Value of Money in Eighteenth-Century England: Incomes, Prices, Buying Power - And Some Problems in Cultural Economics. Huntington Library Quarterly 77 (4): 363-416.

Ioannidis, John. 2005. Why Most Published Research Findings Are False. PLoS Medicine 2 (8): el68.

Jevons, William. 1883. Methods of Social Reform and Other Papers. London: Macmillan and Co..

Journal of the House of Commons. 1753a. From January the 17th, 1750, in the Twenty-fourth Year of the Reign of King George the Second, to April the 6th, 1754, in the Twenty-seventh Year of the Reign of King George the Second. April 6,747. 
1753b. From January the 17th, 1750, in the Twenty-fourth Year of the Reign of King George the Second, to April the 6th, 1754, in the Twenty-seventh Year of the Reign of King George the Second. June 7, 838.

Kant, Immanuel. 1790. Critique of Judgement. Ed Nicholas Walker and Trans. James Creed Meredith (2007). Oxford: Oxford University Press.

Latour, Bruno. 1987. Science in Action: How to Follow Scientists and Engineers Through Society. Cambridge, MA: Harvard University Press.

Lears, Jackson. 2015. Liberal Arts vs. Neoliberalism. Commonweal Magazine. April 20, Accessed 12 June 2016, via www.commonwealmagazine.org/ liberal-arts-vs-neoliberalism

Lemke, Thomas. 2001. The Birth of Bio-Politics: Michel Foucault's Lecture at the Collège de France on Neo-Liberal Governmentality. Economy and Society 30 (2): 190-207.

Logan, Ellen, and Edward Prichard. What Do Graduates Do? November 2016. London: HECSU.

Looseley, David. 2011. Making an 'Impact': Some Personal Reflections on the Humanities in the UK. Arts and Humanities in Higher Education 10 (1): 9-18.

MacDonald, Sharon. 2006. Collecting Practices. In A Companion to Museum Studies, ed. Sharon MacDonald, 81-97. Oxford: Blackwell.

Martin, Ben R. 2011. The Research Excellence Framework and the 'Impact Agenda': Are We Creating a Frankenstein Monster? Research Evaluation 20 (3): 247-254.

Martin, Ben, and Richard Whitley. 2010. The UK Research Assessment Exercise: A Case of Regulatory Capture? In Reconfiguring Knowledge Production: Changing Authority Relationships in the Sciences and Their Consequences for Intellectual Innovation, ed. Richard Whitley, Jochen Glaser, and Lars Engwall, 51-80. Oxford: Oxford University Press.

McCarthy, Kevin F., Elizabeth H Ondaatje, Laura Zakaras, and Arthur Brooks. 2004. Gifts of the Muse: Reframing the Debate about the Benefits of the Arts. The Rand Corporation for the Wallace Foundation (RAND). Accessed 10 Jan 2016, via www.rand.org/pubs/monographs/2005/RAND_MG218.pdf

McLaughlin, Kathleen, Stephen P. Osborne, and Ewan Ferlie. 2002. The New Public Management: Current Trends and Future Prospects, 15-33. London: Routledge.

McRobbie, Angela. 1996. All the World's a Stage, Screen or Magazine: When Culture Is the Logic of Late Capitalism. Media, Culture and Society 18 (2): 335-342.

Miller, Edward. 1973. That Noble Cabinet: A History of the British Museum. London: Andre Deutsch Limited.

Miller, David A. 1988. The Novel and the Police. Cambridge, MA: Harvard University Press.

Mirza, Munira. 2012. The Politics of Culture: The Case for Universalism. Basingstoke: Palgrave Macmillan. 
Moore, Samuel, Cameron Neylon, Martin Paul Eve, Daniel Paul O'Donnell, and Damian Pattinson. 2017. "Excellence R Us": University Research and the Fetishisation of Excellence. Palgrave Communications 3. Accessed via https:// doi.org/10.1057/palcomms.2016.105

O'Connor, Pat, and Clare O'Hagan. 2015. Excellence in University Academic Staff Evaluation: A Problematic Reality? Studies in Higher Education 41 (11): 1943-1957.

Oancea, Alis, and John Furlong. 2007. Expressions of Excellence and the Assessment of Applied and Practice-Based Research. Research Papers in Education 22 (2): 119-137.

O'Brien, Dave. 2010. Measuring the Value of Culture. AHRC/ESRC, London: Department of Culture, Media and Sport.

Ochsner, Michael, E. Hug Sven, and Hans-Dieter Daniel. 2012. Indicators for Research Quality in the Humanities: Opportunities and Limitations. Bibliometrie - Praxis und Forschung 1: 4-1-4-17.

Ochsner, Michael, E. Hug Sven, and Ioana Galleron. 2017. The Future of Research Assessment in the Humanities: Bottom-up Assessment Procedures. Palgrave Communications 3. Accessed via https://doi.org/10.1057/ palcomms.2017.20

Parkin, Frank. 1987. The Mind and Body Shop. London: Fontana Paperbacks.

Parliamentary Papers. 1835. Report from the Select Committee on the Condition, Management and Affairs of the British Museum; Together with the Minutes of Evidence, Appendix and Index. House of Commons Papers. August 6, Accessed 22 Apr 2017. https://parlipapers.proquest.com/parlipapers/docview/t70. d75.1835-015563? accountid=10792

- 1836. Report on the Select Committee on Condition, Management and Affairs of British Museum: Report, Minutes of Evidence, Appendix. House of Commons Papers. July 14. Accessed 22 Apr 2017, via https://parlipapers.proquest.com/parlipapers/docview/t70.d75.1836-016279? accountid=10792

Readings, Bill. 1996. The University in Ruins. Cambridge, MA: Harvard University Press.

REF. 2014. REF: Key Facts. REF 2014. December, Accessed 28 May 2016, via www.ref.ac.uk/2014/media/ref/content/pub/REF\%20Brief\%20Guide\%20 2014.pdf

Research Council UK (RCUK). 2011. Efficiency 2011-15: Ensuring Excellence with Impact. Research Council UK Policy \& Strategy. Accessed 28 May 2016, via www. rcuk.ac.uk/documents/documents/efficiencyensuringexcellencewithimpact-pdf

Roelofs, Patricia, and Max Galien. 2017. Clickbait and Impact: How Academia Has Been Hacked. LSE Impact Blog, September 19, Accessed 3 Jan 2018, via www.blogs.lse.ac.uk/impactofsocialsciences/2017/09/19/clickbait-and-impacthow-academia-has-been-hacked/

Rollock, Nicola. 2013. A Political Investment: Revisiting Race and Racism in the Research Process. Discourse: Studies in the Cultural Politics of Education 34 (4): 492-509. 
Rose, Nikolas. 1991. Governing by Numbers: Figuring Out Democracy. Accounting Organizations and Society 16: 673-692.

Ryan-Flood, Róisín, and Rosalind Gill, eds. 2010. Secrecy and Silence in the Research Process: Feminist Reflections. London: Routledge.

Rylance, Rick. 2016. Literature and the Public Good. Oxford: Oxford University Press.

Sandel, Michael. 2009. A New Politics of the Common Good. The Reith Lectures, June 30, London: BBC Radio 4. Accessible via www.bbc.co.uk/programmes/b00lb6bt

Sastry, Tom, and Bahram Bekhradnia. 2006. Using Metrics to Allocate Research Funds. Oxford: HEPI.

Schlesinger, Philip. 2013. Expertise, the Academy and the Governance of Cultural Policy. Media, Culture \& Society 35 (1): 27-35.

- 2014. The Public Intellectual. CREATe Plenary Speech at All Hands Conference, September 15-6, Glasgow. Accessed 5 Jan 2017, via www.create. ac.uk/blog/2014/07/02/create-all-hands-conference-glasgow-september15-16th-2014/

Selwood, Sara. 2002. The Politics of Data Collection: Gathering, Analyzing and Using Data About the Subsidised Cultural Sector in England. Cultural Trends 12 (47): 13-84.

. 2010. Making a Difference: The Cultural Impact of Museums. Published Essay. London: NMDC. Accessible via http://www.nationalmuseums.org.uk/ media/documents/publications/cultural_impact_final.pdf

Shore, Cris. 2008. Audit Culture and Illiberal Governance: Universities and the Politics of Accountability. Anthropological Theory 8 (3): 278-298.

Sinclair, Andrew. 1995. Arts and Cultures, the History of the 50 Years of the Arts Council of Great Britain. London: Sinclair-Stevenson Ltd..

Sloane, Hans (Sir). 1753. The Will of Sir Hans Sloane, Bart. Deceased. London: John Virtuoso.

Small, Helen. 2013. The Value of the Humanities. Oxford: Oxford University Press.

Smith, Steve. 2011. Afterword: A Positive Future for Higher Education in England. In A Manifesto for the Public University, ed. John Holmwood, 127-142. London: Bloomsbury Academic.

Smith, Simon, Vicky Ward, and Allan House. 2011. 'Impact' in the Proposals for the UK's Research Excellence Framework: Shifting the Boundaries of Academic Autonomy. Research Policy 40: 1369-1379.

Spaapen, Jack, Huub Dijstelbloem, and Frank Wamelink. 2007. Evaluating Research in Context: A Method for Comprehensive Assessment. 2nd ed. The Hague: Consultative Committee of Sector Councils for Research and Development (COS).

Stern, Nicholas. 2016. Building on Success and Learning from Experience An Independent Review of the Research Excellence Framework. Independent Review, London: HMSO. 
Stilgoe, Jack. 2014. Against Excellence. The Guardian, December 19, Accessed 3 June 2017, via www.theguardian.com/science/political-science/2014/dec/ $19 /$ against-excellence

Syntax. 1825. Letter to the Editor. The Times, November 18, 4.

Taylor, Brandon. 1999. Art for the Nation: Exhibitions and the London Public 1747-2001. Manchester: Manchester University Press.

Tenniel, John. 1869. The Sunday Question. The Public House; or, The House For The Public? April 17, London: Punch.

Thatcher, Margaret. 1981. Interview for the Sunday Times. Interview by Ronald Butt May 3, London: Sunday Times. Accessed via www.margaretthatcher.org/ document/104475

Thomas, David Wayne. 2004. Cultivating Victorians: Liberal Culture and the Aesthetic. Philadelphia: University of Pennsylvania Press.

Tusa, John. 2000. Art Matters: Reflecting on Culture. London: Methuen.

UNESCO. 2015. Wider Value of UNESCO to the UK. 2014-2015. November, National Commission for UNESCO. Accessed via www.unesco.org.uk/wpcontent/uploads /2016/02/UK-National-Commission-for-UNESCO_ Wider-Value-of-UNESCO-to-the-UK_UK-Organisations_January-2016.pdf

van Aalst, Irina, and Inez Boogaarts. 2002. From Museum to Mass Entertainment: The Evolution of the Role of Museums in Cities. European Urban and Regional Studies 9: 195-209.

Wilson, David. 2002. The British Museum: A History. London: The British Museum Press.

Young, Paul. 2009. Globalization and the Great Exhibition: The Victorian New World Order. Basingstoke: Palgrave Studies in Nineteenth-Century Writing and Culture.

Open Access This chapter is licensed under the terms of the Creative Commons Attribution 4.0 International License (http://creativecommons.org/licenses/ by $/ 4.0 /$ ), which permits use, sharing, adaptation, distribution and reproduction in any medium or format, as long as you give appropriate credit to the original author(s) and the source, provide a link to the Creative Commons licence and indicate if changes were made.

The images or other third party material in this chapter are included in the chapter's Creative Commons licence, unless indicated otherwise in a credit line to the material. If material is not included in the chapter's Creative Commons licence and your intended use is not permitted by statutory regulation or exceeds the permitted use, you will need to obtain permission directly from the copyright holder.

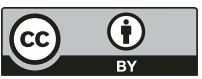

